\title{
Influence of Sodium Sulfate Addition on Iron Grain Growth during Carbothermic Roasting of Red Mud Samples with Different Basicity
}

\author{
Pavel Grudinsky ${ }^{1, *(D)}$, Dmitry Zinoveev ${ }^{1}\left(\mathbb{D}\right.$, Denis Pankratov ${ }^{2}{ }^{(0}$, Artem Semenov $^{1}$, \\ Maria Panova ${ }^{1}$, Alex Kondratiev ${ }^{3}$, Andrey Zakunov ${ }^{1,3}$, Valery Dyubanov ${ }^{1}$ and \\ Alexander Petelin ${ }^{3}$ \\ 1 Laboratory of Physical Chemistry and Technology of Iron Ore Processing, A.A. Baikov Institute of \\ Metallurgy and Materials Science, Russian Academy of Science, 49 Leninsky Prosp, 119334 Moscow, Russia; \\ dzinoveev@imet.ac.ru (D.Z.); SemenovArtem2019@yandex.ru (A.S.); maxi4@list.ru (M.P.); \\ az437@yandex.ru (A.Z.); vdyubanov@imet.ac.ru (V.D.) \\ 2 Department of Radiochemistry, Faculty of Chemistry, Lomonosov Moscow State University (MSU), \\ 1-3 Leninskiye Gory, 119991 Moscow, Russia; pankratov@radio.chem.msu.ru \\ 3 National University of Science \& Technology (MISIS), 4 Leninsky Prosp, 119049 Moscow, Russia; \\ a_kondratiev@misis.ru (A.K.); sasha@misis.ru (A.P.) \\ * Correspondence: pgrudinskiy@imet.ac.ru; Tel.: +7-499-135-6316
}

Received: 20 October 2020; Accepted: 21 November 2020; Published: 24 November 2020

\begin{abstract}
Red mud is an iron-containing waste of alumina production with high alkalinity. A promising approach for its recycling is solid-phase carbothermic roasting in the presence of special additives followed by magnetic separation. The crucial factor of the separation of the obtained iron metallic particles from gangue is sufficiently large iron grains. This study focuses on the influence of $\mathrm{Na}_{2} \mathrm{SO}_{4}$ addition on iron grain growth during carbothermic roasting of two red mud samples with different $(\mathrm{CaO}+\mathrm{MgO}) /\left(\mathrm{SiO}_{2}+\mathrm{Al}_{2} \mathrm{O}_{3}\right)$ ratio of 0.46 and 1.21 , respectively. Iron phase distribution in the red mud and roasted samples were investigated in detail by Mössbauer spectroscopy method. Based on thermodynamic calculations and results of multifactorial experiments, the optimal conditions for the roasting of the red mud samples with $(\mathrm{CaO}+\mathrm{MgO}) /\left(\mathrm{SiO}_{2}+\mathrm{Al}_{2} \mathrm{O}_{3}\right)$ ratio of 0.46 and 1.21 were duration of $180 \mathrm{~min}$ with the addition of $13.65 \% \mathrm{Na}_{2} \mathrm{SO}_{4}$ at $1150{ }^{\circ} \mathrm{C}$ and $1350{ }^{\circ} \mathrm{C}$ followed by magnetic separation that led to $97 \%$ and $83.91 \%$ of iron recovery, as well as $51.6 \%$ and $83.7 \%$ of iron grade, respectively. The mechanism of sodium sulfate effect on iron grain growth was proposed. The results pointed out that $\mathrm{Na}_{2} \mathrm{SO}_{4}$ addition is unfavorable for the red mud carbothermic roasting compared with other alkaline sulfur-free additives.
\end{abstract}

Keywords: red mud; bauxite residue; reduction roasting; sodium sulfate; iron grain growth; magnetic separation; recycling; utilization

\section{Introduction}

According to some estimates [1], the world industry produced over 132 million tons of alumina in 2019. It is well-known that alumina production is accompanied by considerable generation of waste: 1 ton of alumina produces about 1-1.5 tons of waste called the bauxite residue or red mud [2]. Currently, total globally accumulated amount of red mud is about 4.6 billion ton [3]. High alkalinity and significant content of toxic components make red mud potentially dangerous to the environment and human health [4-6], so it is necessary to utilize it.

There were a lot of efforts to recycle red mud by numerous methods. Many studies investigated extraction of valuable components [7-9] with a particular focus on iron [10,11] as a major red mud 
component [12] and rare-earth metals [13-16] as a critical material for many important technologies [17]. A common approach involves utilization of red mud in construction industry [18], namely in production of cement [19], concrete [20], bricks [21,22], geopolymers [23], etc. Some studies considered its use as an adsorbent [24], catalyst [25] and coagulant [26]. However, nowadays, the world industry utilizes only up to $3 \%$ of annually generated red mud [27].

A promising and recently studied approach for red mud recycling is solid-phase reduction of iron at $1050-1400{ }^{\circ} \mathrm{C}$ [28], that is evidently more cost effective than reduction smelting at temperatures above $1500{ }^{\circ} \mathrm{C}$ [29] because of a lower energy consumption. This approach had been used for other different iron-containing wastes [30-32], as well as complex low-grade iron [33-35] and nickel [36-38] ores. High-grade metallized concentrates and tailings with high content of other valuable components can be obtained by carbothermic reduction followed by magnetic separation. In the case of processing of red mud besides metallized iron concentrate or even metallic iron powder [39], increased contents of aluminum, titanium and rare-earth metals can be obtained in the tailings, making it more viable for subsequent recycling.

It is noteworthy that the carbothermic reduction approach has an important feature associated with fine impregnation of iron with gangue or general particle fineness of raw materials. Reduction of such materials frequently forms finely grained metallic iron, which is impossible to be magnetically separated from gangue [40]. Hence, to promote iron grain segregation, special additives are used, mainly alkali and alkaline earth metal salts. If $\mathrm{Na}_{2} \mathrm{CO}_{3}$ [41-43], $\mathrm{Na}_{2} \mathrm{SO}_{4}$ [39,44-46], $\mathrm{Na}_{2} \mathrm{~B}_{4} \mathrm{O}_{7}$ [47], $\mathrm{K}_{2} \mathrm{CO}_{3}$ [48], $\mathrm{KCl}$ [49], $\mathrm{CaF}_{2}$ [50] were used for solid-phase carbothermic reduction of red mud, high iron recovery and high grade of the concentrates could have been achieved. As reported in our previous work [48], the roasting of red mud with addition of $17.1 \% \mathrm{Na}_{2} \mathrm{CO}_{3}$ or $22.05 \% \mathrm{~K}_{2} \mathrm{CO}_{3}$ at $1300{ }^{\circ} \mathrm{C}$ for $180 \mathrm{~min}$ followed by magnetic separation resulted in iron recovery of $77.27 \%$ and $85.54 \%$, respectively, and iron concentrate with grade of about $72 \%$ in both cases.

It is acknowledged that sodium sulfate is one of the most used additives for carbothermic reduction of other materials containing iron [51-53] and nickel [54-56]. Previous studies have shown that $\mathrm{Na}_{2} \mathrm{SO}_{4}$ facilitates iron grain growth superior to other additives [57], so, to improve the results previously obtained with alkali carbonates [48], sodium sulfate is used in this work as an additive for carbothermic roasting of red mud.

It is well-known that addition of $\mathrm{CaO}$ during sodium sintering of red mud (sinter leach process) leads to the formation of $\mathrm{Ca}_{2} \mathrm{SiO}_{4}$ phase, which improves subsequent aluminum recovery by leaching [58-60]. On the other hand, $\mathrm{CaO}$ addition can decrease iron content in the magnetic concentrates obtained after solid phase reduction at low temperatures [61,62].

In this paper, we studied the effect of $\mathrm{Na}_{2} \mathrm{SO}_{4}$ addition on carbothermic reduction and magnetic separation of two different samples of red mud with various contents of $\mathrm{CaO}$ and $\mathrm{Fe}$ by thermodynamic analysis and laboratory experiments. The effect of temperature, amount of the additive and roasting time on iron grain growth and its separation from gangue was studied. The optimal conditions for the carbothermic reduction of red mud in the presence of sodium sulfate were determined. The mechanism of the effect of $\mathrm{Na}_{2} \mathrm{SO}_{4}$ on grain growth of reduced iron was proposed.

\section{Materials and Methods}

\subsection{Raw Materials}

Two samples of the industrial red mud were used to study the effect of sodium sulfate addition. One of the samples codenamed as B was brought from Bogoslovsky Aluminium Plant (Russian Federation, Sverdlovsk region, Krasnoturyinsk, 59.84 $\left.\mathrm{N}, 60.19^{\circ} \mathrm{E}\right)$. The other sample codenamed as U was obtained from red mud of Ural Aluminum Plant (Russian Federation, Sverdlovsk region, Kamensk-Uralsky, $56.30^{\circ} \mathrm{N} 61.98^{\circ} \mathrm{E}$ ) by $3 \mathrm{~h}$ lime water treatment at $90^{\circ} \mathrm{C}$ [63]. 


\subsection{Thermodynamic Simulation}

HSC Chemistry 9.9 software (Outotec, Pori, Finland) [64] was used for equilibrium simulation. The calculation was performed at $1100{ }^{\circ} \mathrm{C}$ in $100 \% \mathrm{~N}_{2}$ at pressure of $0.1 \mathrm{MPa}$ for $100 \mathrm{~kg}$ of red mud and addition of $40 \%$ C (graphite).

\subsection{Experimental Procedure}

Reducing agent was long-flaming coal with ash and moisture contents of $15 \%$ and $18 \%$, respectively. The additive was a reagent-grade $\mathrm{Na}_{2} \mathrm{SO}_{4}$. Red mud, coal, and the additive were ground in a mortar with a pestle to sift through a screen with an aperture of $0.200 \mathrm{~mm}$.

The red mud samples and sodium sulfate were dehydrated at $105{ }^{\circ} \mathrm{C}$ for $120 \mathrm{~min}$ and were mixed in a V-shell blender for $720 \mathrm{~min}$. The $\mathrm{Na}_{2} \mathrm{SO}_{4}$ amounts after following conversion corresponded to $2.5,5.0,7.5,10.0,12.5$ and $15.0 \mathrm{wt}$ \% $\mathrm{Na}_{2} \mathrm{~S}$ were added to $100 \%$ of red mud. The tablets from $1 \mathrm{~g}$ of the powder mixtures were prepared by a hand hydraulic press and a mold with a diameter of $17 \mathrm{~mm}$ using a pressure of $215 \mathrm{MPa}$.

Two corundum crucibles were used in the carbothermic roasting experiments with height/diameter ratio of $62 / 45$ and $68 / 58 \mathrm{~mm}$, respectively. Figure 1 shows the layout diagram of the tablets and coal in the experiments.

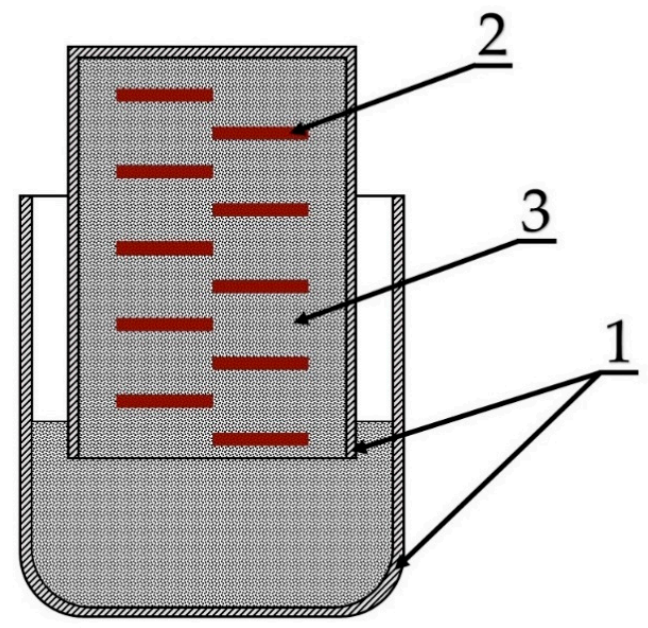

Figure 1. Schematic diagram of mutual arrangement of the raw materials in the roasting experiments, where 1-corundum crucibles; 2 - the tablets containing red mud and sodium sulfate; 3 -coal.

The samples prepared were roasted in the range of $1000-1450{ }^{\circ} \mathrm{C}$ in a muffle-type furnace with $\mathrm{S}$-type $\mathrm{Pt} / \mathrm{Pt}$-Rh control thermocouple. The crucibles with the tablets were placed into the preheated furnace, roasted for a certain time, taken out and quenched into liquid nitrogen.

The chemical composition of the red mud samples was analyzed by an inductively coupled plasma atomic emission spectrometer (ICP AES) Vista Pro (Varian Optical Spectroscopy Instr., Mulgrave, Australia). The X-ray diffraction (XRD) data were collected by an ARL X'tra diffractometer (Thermo Fisher Scientific, Ekublens, Switzerland) with a $\mathrm{Cu}$ anode. The obtained XRD patterns were interpreted using Match! Software (Crystal Impact, Bonn, Germany) [65]. To analyze the roasted samples, concentrates, and tailings, they were ground to sift through a screen with an aperture of $0.054 \mathrm{~mm}$. The chemical analysis of the total Fe content was carried out after proper sample digestion by an atomic absorption spectrometry (AAS) method using AA240FS (Varian Inc., Palo Alto, Santa Clara, CA, USA) device or by complexometric titration method in the case of iron contents more than $30 \%$. Complexometric titration was carried out by $0.025 \mathrm{M}$ solution of Trilon B using 20-25\% sulfosalicylic acid as an indicator at $\mathrm{pH}=2-3$ until the color change from blue-violet to lemon-yellow.

A Mössbauer spectrometer MS-1104EM (CJSC Cordon, Rostov-on-Don, Russia) was used to collect spectra of the red mud and roasted samples at $77.5 \pm 0.3 \mathrm{~K}$ and/or at room temperature $(296 \pm 3 \mathrm{~K})$. 
The ${ }^{57}$ Co nuclei in a matrix of metallic $\mathrm{Rh}$ with $47 \mathrm{mCi}$ activity were used as the source of gamma-radiation. The spectra were recorded in high-resolution mode (1024 points) with the noise/signal ratio of less than 1.0 and $1.5 \%$ for initial and roasted samples, respectively. SpectrRelax 2.4 software (Lomonosov MSU, Moscow, Russia) was applied for processing of the Mössbauer spectra. The chemical shift values were given relative to $\alpha$-Fe.

\subsection{Calculation of Iron Grain Size}

A reflected-light METAM LV-34 (LOMO-Mikrosistemy, Saint Petersburg, Russia) optical microscope and a RisingCam RT5109 (RisingTech, Chengdu, Sichuan, China) camera were used to obtain photomicrographs in 50-250× magnification of the metallographic specimens prepared from the roasted samples. Image Pro Plus software (Media Cybernetics, Rockville, MD, USA) was used for image analysis of the 16 stitched photomicrographs and for iron grain size calculation. To characterize the iron grain size, area and average Feret diameter in all directions were calculated for all the grains, besides the very small ones up to $0.0002 \mathrm{~mm}$, which were excluded from the calculation results. The Feret diameter is the distance between two parallel lines that bound an object perpendicular to a certain direction. Based on the calculation data, the dependences of relative area of iron grains of different fractions on the roasting conditions was obtained.

\subsection{Magnetic Separation}

The roasted red mud samples were ground and sifted through a screen with an aperture of $0.054 \mathrm{~mm}$, then a dry drum magnetic separator BSMK-200 (LLC Industrial magnets, Kaluga, Russia) with magnetic strength of $0.35 \mathrm{~T}$ was applied to obtain iron magnetic concentrate and non-magnetic tailings. The concentrate yield was calculated as follows:

$$
\gamma=m_{c} / m_{0} \times 100 \%
$$

where $\gamma$ is the concentrate yield, $\% ; m_{0}$ is the mass of the roasted sample, $\mathrm{g} ; m_{\mathrm{c}}$ is the mass of the concentrate obtained by magnetic separation, $\mathrm{g}$.

The recovery of iron was determined as follows:

$$
\varepsilon=\left(m_{c} \times \% F e_{c}\right) /\left(m_{0} \times \% F e_{0}\right) \times 100 \%
$$

where $\varepsilon$ is the recovery of iron, $\% ; \% F e_{\mathrm{c}}$ and $\% F e_{o}$ are the total iron content in the concentrate and roasted sample, respectively, \%.

\section{Results}

\subsection{Red Mud Samples Characterization}

Table 1 shows the chemical composition of two red mud samples. It can be seen that the $\mathrm{Fe}_{2} \mathrm{O}_{3}$ content in the sample B is almost $50 \%$, which is promising for iron extraction, but high percentage of $\mathrm{Na}_{2} \mathrm{O}$ is one of the adverse factors for this purpose by conventional industrial methods, e.g., blast furnace smelting. The sample $U$, which was leached by lime milk, has insignificant sodium content, but due to the calcium enrichment by the treatment, a percentage of valuable components such as iron, aluminum and scandium is less. Accordingly, the basicity $(\mathrm{CaO}+\mathrm{MgO}) /\left(\mathrm{SiO}_{2}+\mathrm{Al}_{2} \mathrm{O}_{3}\right)$ of the samples $\mathrm{B}$ and $\mathrm{U}$ differs considerably and is 0.46 and 1.21 , respectively.

Figure 2 compares the diffractograms of the samples $\mathrm{B}$ and $\mathrm{U}$ with phase signs. The main minerals of both samples are hematite $\left(\mathrm{Fe}_{2} \mathrm{O}_{3}\right)$ and katoite $\left(\mathrm{Ca}_{3} \mathrm{Al}_{2} \mathrm{Si}_{3}(\mathrm{OH})_{12}\right)$, but the minor phases are different. The sample $\mathrm{B}$ contains few hydrated aluminum phases, namely kaolinite $\left(\mathrm{Al}_{2} \mathrm{Si}_{2} \mathrm{O}_{5}(\mathrm{OH})_{4}\right)$, hydrogarnet $\left(\mathrm{Al}_{2} \mathrm{Ca}_{3}(\mathrm{OH})_{12}\right)$, diaspore $(\mathrm{AlOOH})$, while they are undetected in the sample U. Probably, the sample $\mathrm{B}$ can contain some of these phases in lower contents, but due to high peaks of $\mathrm{CaCO}_{3}$ and $\mathrm{Ca}(\mathrm{OH})_{2}$ transferred from leaching solution, they are imperceptible. 
Table 1. Chemical composition of the red mud samples (wt.\%).

\begin{tabular}{ccccccccccccc}
\hline $\begin{array}{c}\text { Aluminum } \\
\text { Plant }\end{array}$ & Codename & $\mathrm{Fe}_{2} \mathrm{O}_{3}$ & $\mathrm{SiO}_{2}$ & $\mathrm{Al}_{2} \mathrm{O}_{3}$ & $\mathrm{TiO}_{2}$ & $\mathrm{CaO}$ & $\mathrm{MgO}$ & $\mathrm{MnO}$ & $\mathbf{N a}_{2} \mathrm{O}$ & $\mathbf{P}_{2} \mathrm{O}_{5}$ & $\mathbf{S}$ & $\mathbf{S c}$ \\
\hline Bogoslovsky & $\mathrm{B}$ & 49.81 & 8.71 & 12.77 & 4.67 & 9.26 & 0.65 & 0.26 & 3.30 & 0.85 & 0.48 & 0.014 \\
\hline Ural & $\mathrm{U}$ & 36.9 & 8.71 & 11.80 & 3.54 & 23.8 & 1.01 & 0.95 & 0.27 & 0.42 & 0.14 & 0.008 \\
\hline
\end{tabular}
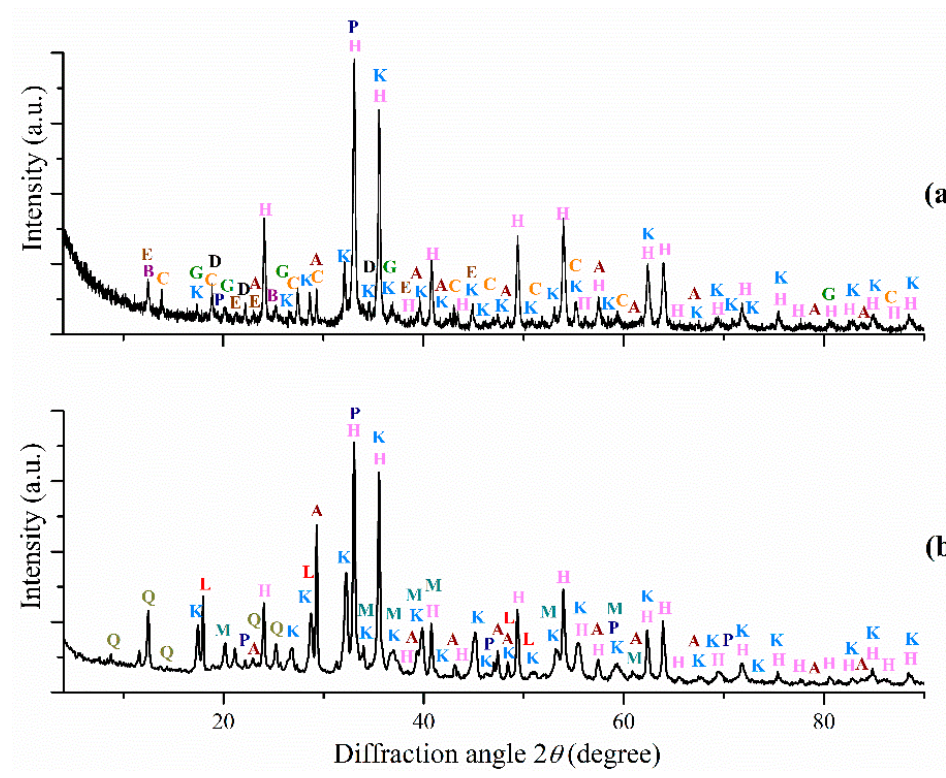

(a)

(b)

Figure 2. The XRD patterns of the red mud samples $\mathrm{B}(\mathbf{a})$ and $\mathrm{U}(\mathbf{b})$, where $\mathrm{H}-\alpha-\mathrm{Fe}_{2} \mathrm{O}_{3} ; \mathrm{K}-$ $\mathrm{Ca}_{3} \mathrm{Al}_{2} \mathrm{Si}_{3}(\mathrm{OH})_{12} ; \mathrm{C}-\mathrm{Na}_{6} \mathrm{Ca}\left(\mathrm{AlSiO}_{4}\right)_{6} \mathrm{CO}_{3} \cdot 2 \mathrm{H}_{2} \mathrm{O} ; \mathrm{E}-\mathrm{Al}_{4}\left[\mathrm{Si}_{4} \mathrm{O}_{10}\right](\mathrm{OH})_{8} ; \mathrm{G}-\mathrm{Al}_{2} \mathrm{Ca}_{3}(\mathrm{OH})_{12} ; \mathrm{A}-\mathrm{CaCO}_{3}$ (calcite); $\mathrm{B}-\left(\mathrm{Na}_{0.3} \mathrm{Ca}_{0.1} \mathrm{~K}_{0.1}\right)\left(\mathrm{Mn}^{4+}, \mathrm{Mn}^{3+}\right)_{2} \mathrm{O}_{4} \cdot 1.5 \mathrm{H}_{2} \mathrm{O} ; \mathrm{D}-\gamma-\mathrm{AlOOH} ; \mathrm{P}-\mathrm{CaTiO}_{3} ; \mathrm{M}-\alpha-\mathrm{FeOOH} ; \mathrm{L}-$ $\mathrm{Ca}(\mathrm{OH})_{2} ; \mathrm{Q}-\mathrm{SiO}_{2}$.

Figure 3 and Table 2 compare the Mössbauer spectra of the red mud samples obtained at room temperature and at low temperature.

It can be seen that the spectra of both samples are similar to each other and consist of a sextet distorted into the internal part of the spectra, two additional lines (asymmetric in intensity) in the internal part of the spectra and a broad resonance line in the middle of the spectra. The sample $U$ spectrum differs from the sample B spectrum by the presence of additional absorption between the resonance lines 1-2-3 and 4-5-6 of the sextet in the room-temperature spectrum, by the presence of shoulders in the lines 1 and 6 of the sextet in the low-temperature spectrum, by high intensity, small width and low asymmetry of two additional lines in the internal part of the spectra, and by low intensity of the middle line of the spectra. A decrease of temperature results in an insignificant decrease of the intensity of the broad middle line of the U spectrum, while the intensity of paramagnetic part (asymmetric doublet and broad middle line) of the B spectrum is practically independent of temperature. It can be concluded that asymmetry of the resonance lines of the sextets at room temperature cannot be caused only by superparamagnetism (characteristic for nano- or highly dispersed iron particles) [66], but can be resulted from locally inhomogeneous environment of Fe atoms, at least in one phase present in the samples. On the other hand, the shoulders in the low-temperature spectrum of the U sample and the resonance lines out of the base line indicate superposition of the spectra of at least two magnetically ordered phases, one of which is responsible for distortion of the background line in the middle part of the spectrum at room temperature.

The spectra obtained at room temperature can satisfactory be described as superposition of four (for the sample B) or six (for the sample U) sextets and two doublets (Table 2). Six sextets for the sample $\mathrm{U}$ include of four subspectra that are analogous to those for the sample B and two additional 
subspectra. The low-temperature spectra of both samples are satisfactory described as superposition of three sextets and two doublets.

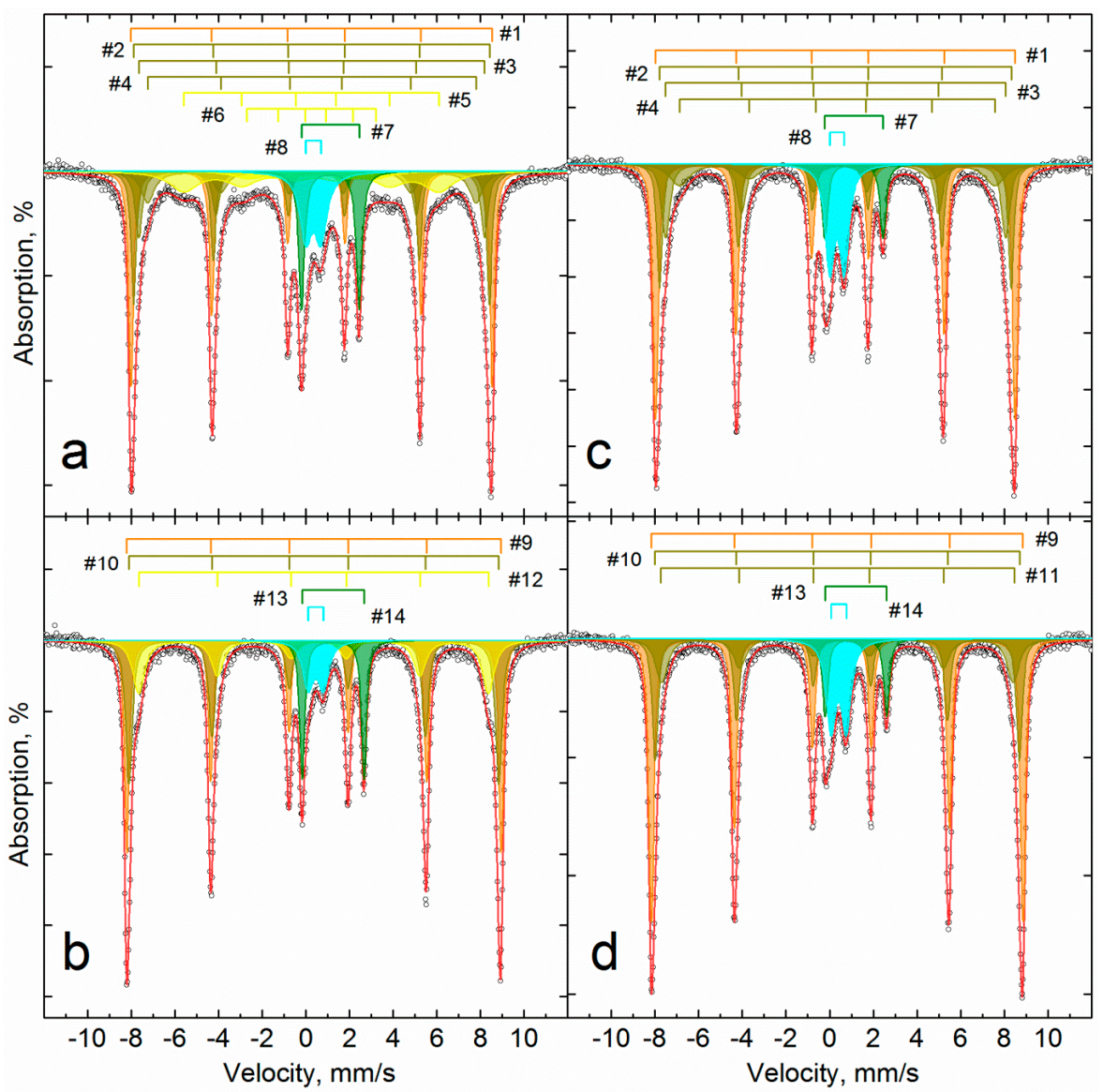

Figure 3. Mössbauer spectra obtained at $296 \mathrm{~K}(\mathbf{a}, \mathbf{c})$ and $77.5 \mathrm{~K}(\mathbf{b}, \mathbf{d})$ of the red mud samples $\mathrm{U}(\mathbf{a}, \mathbf{b})$ and $\mathrm{B}(\mathbf{c}, \mathbf{d})$ and their model description with numbering of subspectra according to Table 2.

Table 2. Mössbauer spectra parameters and iron phase distribution in the red mud samples $B$ and $U$, where $\delta$-chemical shift; $\Delta=2 \varepsilon$-quadrupole splitting; $\Gamma_{\exp }$-line width; $\mathrm{H}_{\mathrm{eff}}$-hyperfine magnetic field; S- site \# area.

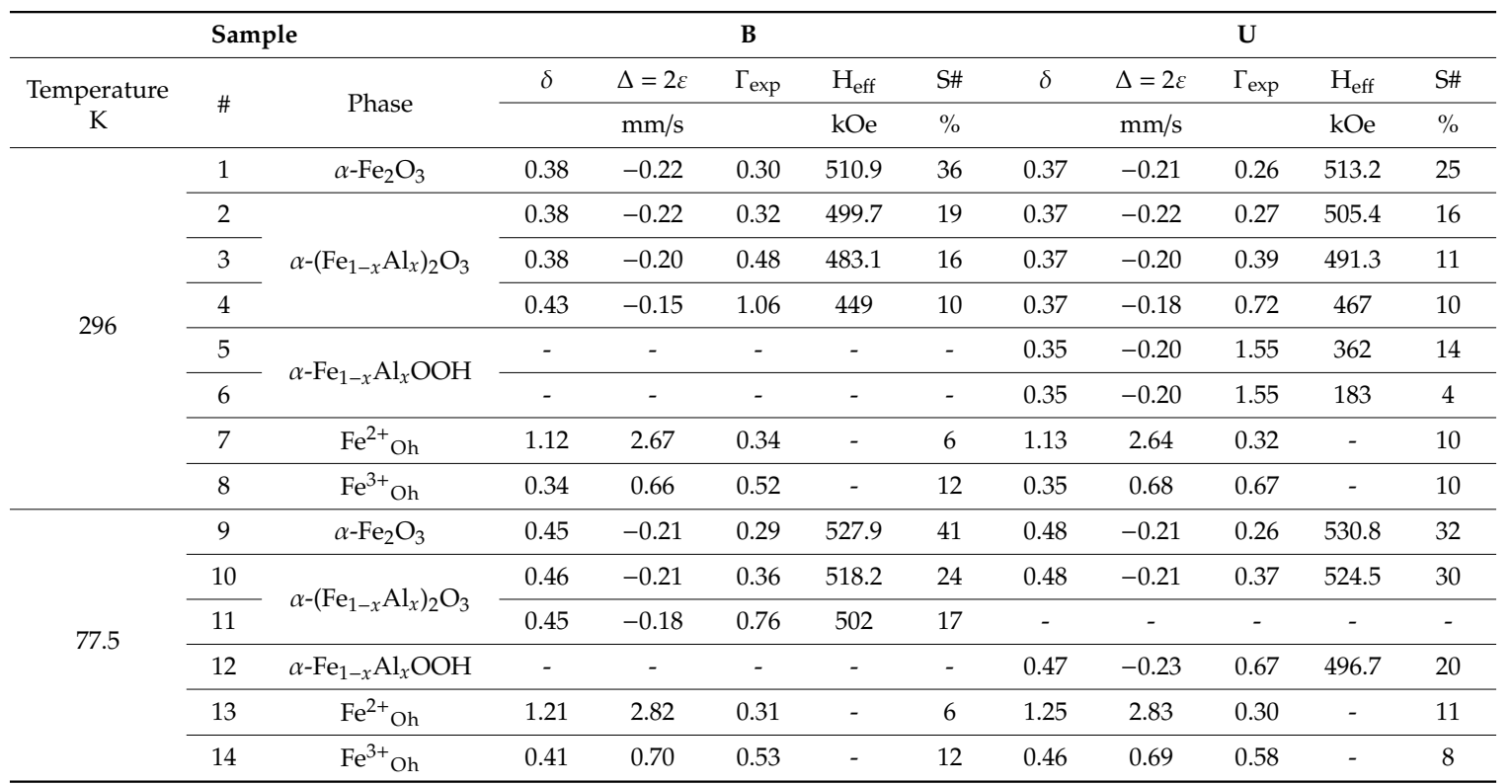


The detailed description of the spectra for the sample $U$ is presented in [67]. The subspectra parameters of the sample B is similar to those of the sample U. The main difference of the B sample spectra is the absence of subspectra 5,6, and 12. This group of sextets, which is present only in the sample U spectra, lowers the background in the middle part of the room-temperature spectrum, and brings about the shoulder in the resonance lines 1 and 6 of the sextets in the low-temperature spectrum. This group of sextets corresponds to alumogoethite, i.e., goethite [68-70], in which part of Fe atoms is isomorphically substituted by Al [71].

The first four sextets in the room-temperature spectra (1-4, Table 2) are common for both samples. The parameters of the sextet 1 are quite similar to the parameters characteristic for hematite [68,72]. The internal sextets $2-4$ that are broader, have lower intensity and lower magnetic splitting than the sextet 1 correspond to defect hematite structures different by a degree of isomorphic substitution of $\mathrm{Fe}$ atoms by $\mathrm{Al}$ atoms [73].

In the low-temperature spectra, these "phases" are represented by two or three sextets (9-11, Table 2) that differ by the width of resonance lines. The presence of $\mathrm{Al}$ atoms in iron sublattice leads to a lower value of the magnetic splitting for the external sextet than that characteristic for hematite [68] and to the absence of the Morin transition [74] in the investigated temperature interval. It should be noted that a decrease of the Morin transition temperature can be caused by an increase of the hydroxyl content in the oxygen sites of alumohematite [75]. Lower magnetic splitting and broadening of the resonance lines in the subspectra of the B sample compared to those of the U sample indicate lower magnetic ordering of the B sample.

The paramagnetic part of the spectra of both samples includes two doublets that correspond to atoms $\mathrm{Fe}^{2+}(7$ and 13 , Table 2$)$ and $\mathrm{Fe}^{3+}$ (8 and 14, Table 2$)$ in high-spin state in octahedral oxygen surrounding [76]. The width of the resonance lines for the $\mathrm{Fe}^{2+}$ doublet is significantly lower than the width of the second doublet and does not change with temperature. On the contrary, the quadrupole splitting of this doublet significantly increases with temperature decreasing. This indicates that this subspectrum corresponds to a unified well-crystallised phase, containing $\mathrm{Fe}^{2+}$ ions. Judging by the value of the quadrupole splitting and its temperature dependence, it can assume that this subspectum corresponds to one of alumosilicate minerals [77].

The relative intensity of the $\mathrm{Fe}^{3+}$ doublet (nos. 8 and 14) of the sample $\mathrm{B}$, different from the $\mathrm{U}$ sample, is twice higher than that of the $\mathrm{Fe}^{2+}$ doublet. Moreover, this doublet has much broader lines, which indicates that this subspectrum is a superposition of several sub-subspectra with closer parameters, corresponding to several phases, and also that these phases have lower degree of crystallinity. The intensity of this doublet for the sample $U$ changes insignificantly, since it contains a paramagnetic part of alumogeothite in the room-temperature spectrum. The sample B, which does not contain this phase, has almost no temperature dependence of the intensity and quadrupole splitting, which excludes the description of this doublet as from superparamagnetic particles, similar to [78].

Thus, the main iron-containing phase of the sample B is hematite, while in the sample $U$ besides hematite/alumohematite there is a considerable content of alumogoethite.

\subsection{Thermodynamic Calculations}

The thermodynamic calculations by HSC Chemistry 9.9 software were carried out to compare a behavior of different components in the samples $\mathrm{B}$ and $\mathrm{U}$ during carbothermic roasting in the presence of $\mathrm{Na}_{2} \mathrm{SO}_{4}$. Based on the results of elemental and phase analyses and Mössbauer spectroscopy, the model compositions of the red mud samples were constructed as follows:

Red mud B, wt.\%: 49.81- $\mathrm{Fe}_{2} \mathrm{O}_{3} ; 11.27-\mathrm{Ca}_{3} \mathrm{Al}_{2} \mathrm{Si}_{3} \mathrm{O}_{12} ; 6.72-\mathrm{Al}_{2} \mathrm{O}_{3} \cdot 2 \mathrm{SiO}_{2} \cdot 2 \mathrm{H}_{2} \mathrm{O} ; 2.10-$ $3 \mathrm{CaO} \cdot \mathrm{Al}_{2} \mathrm{O}_{3} \cdot 2 \mathrm{H}_{2} \mathrm{O} ; 7.95-\mathrm{CaTiO}_{3} ; 4.17-\mathrm{CaCO}_{3} ; 8.24-\mathrm{AlOOH} ; 2.04-\mathrm{CaSO}_{4} ; 0.65-\mathrm{MgO} ; 3.30-\mathrm{Na}_{2} \mathrm{O}$; $1.07-\mathrm{SiO}_{2} ; 0.85-\mathrm{P}_{2} \mathrm{O}_{5}$.

Red mud U, wt.\%: 29.89- $\mathrm{Fe}_{2} \mathrm{O}_{3} ; 7.80-\mathrm{FeOOH} ; 14.97-\mathrm{Ca}_{3} \mathrm{Al}_{2} \mathrm{Si}_{3} \mathrm{O}_{12} ; 3.54-\mathrm{Al}_{2} \mathrm{O}_{3} \cdot 2 \mathrm{SiO}_{2} \cdot 2 \mathrm{H}_{2} \mathrm{O}$; $8.90-\mathrm{Ca}(\mathrm{OH})_{2} ; 6.02-\mathrm{CaTiO}_{3} ; 15.61-\mathrm{CaCO}_{3} ; 8.26-\mathrm{AlOOH} ; 0.59-\mathrm{CaSO}_{4} ; 1.01-\mathrm{MgO} ; 0.27-\mathrm{Na}_{2} \mathrm{O}$; $1.07-\mathrm{SiO}_{2} ; 0.97-\mathrm{P}_{2} \mathrm{O}_{5}$. 
All the species were set as pure with the activity coefficient of 1 . Due to difficulty of iron carburizing process, iron carbides were excluded from the calculation.

Figures 4 and 5 show the results of the calculation for the red mud samples $B$ and $U$, respectively.

It can be seen that full iron metallization is possible both in the absence and in the presence of $\mathrm{Na}_{2} \mathrm{SO}_{4}$. Goethite contained in the sample $\mathrm{U}$ thermally decomposes into hematite at $210-350{ }^{\circ} \mathrm{C}$ [79]. It is well-known that the carbothermic reduction of hematite, which is the main phase of the red mud samples, occurs gradually as follows: $\mathrm{Fe}_{2} \mathrm{O}_{3} \rightarrow \mathrm{Fe}_{3} \mathrm{O}_{4} \rightarrow \mathrm{FeO} \rightarrow \mathrm{Fe}$ [80]. In addition, it is notable that sulfur, which is harmful impurity for steelmaking, generates iron-free compounds, so it can be favorable to obtain a good-quality concentrate for ferrous metallurgy by carbothermic roasting of red mud with sodium sulfate followed by magnetic separation.

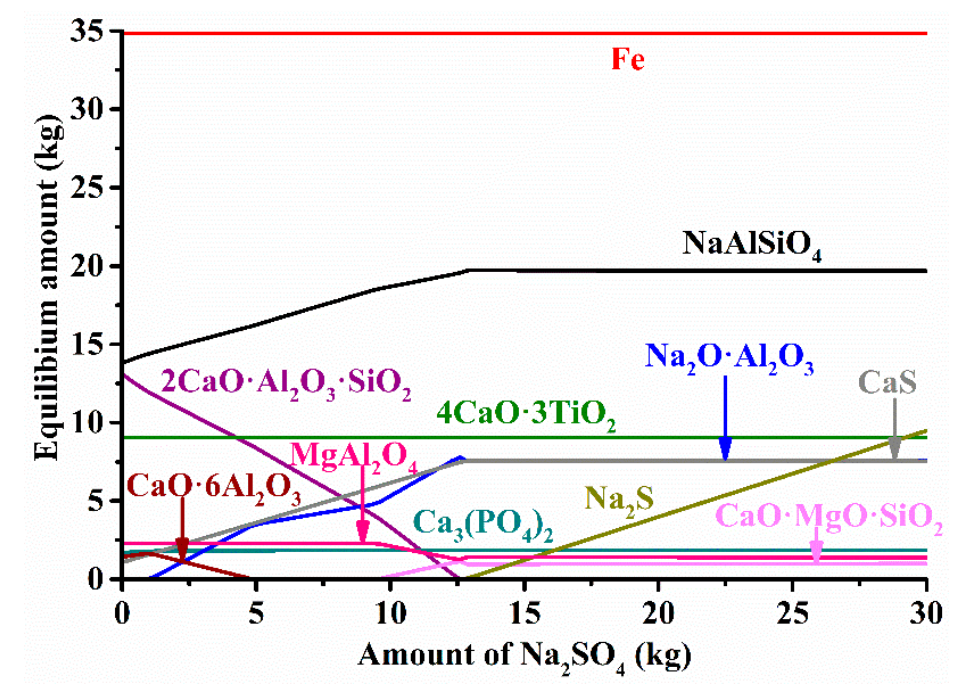

Figure 4. Effect of the $\mathrm{Na}_{2} \mathrm{SO}_{4}$ addition on the equilibrium amounts of different phases at $1100{ }^{\circ} \mathrm{C}$ in the system that comprises $100 \%$ of the red mud sample B and $40 \%$ C.

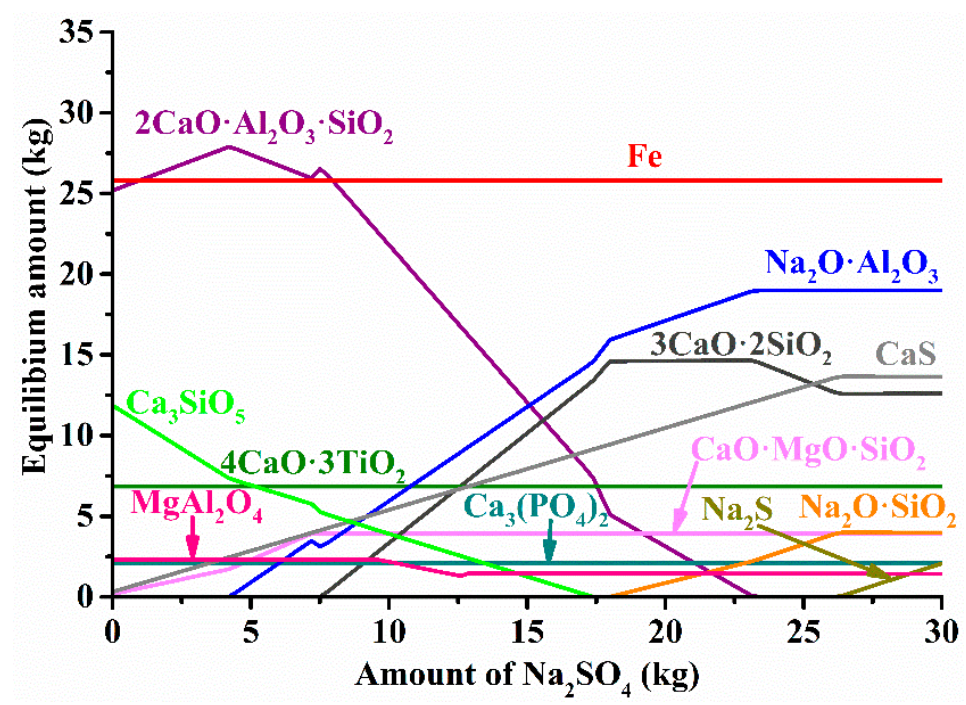

Figure 5. Effect of the $\mathrm{Na}_{2} \mathrm{SO}_{4}$ addition on the equilibrium amounts of different phases at $1100{ }^{\circ} \mathrm{C}$ in the system that comprises $100 \%$ of the red mud sample $U$ and $40 \% \mathrm{C}$.

Apparently, the following general reactions take place in the presence of sodium sulfate:

$$
\begin{gathered}
\mathrm{Na}_{2} \mathrm{SO}_{4}+4 \mathrm{C}=\mathrm{Na}_{2} \mathrm{~S}+4 \mathrm{CO}_{(\mathrm{g})} ; \\
\mathrm{Na}_{2} \mathrm{~S}+\mathrm{CaO}+\mathrm{Al}_{2} \mathrm{O}_{3}=\mathrm{CaS}+\mathrm{Na}_{2} \mathrm{O} \cdot \mathrm{Al}_{2} \mathrm{O}_{3} ;
\end{gathered}
$$




$$
\mathrm{Na}_{2} \mathrm{~S}+\mathrm{CaO}+\mathrm{Al}_{2} \mathrm{O}_{3}+2 \mathrm{SiO}_{2}=\mathrm{CaS}+2 \mathrm{NaAlSiO}_{4} .
$$

The Reaction (3) always occurs in the presence of sodium sulfate and carbon at reducing conditions [81]. A behavior of the Reactions (4) and (5) depends on chemical composition of the raw materials. In the system with red mud sample $B$ (Figure 4) the Reactions (4) and (5) generate $\mathrm{Na}_{2} \mathrm{O} \cdot \mathrm{Al}_{2} \mathrm{O}_{3}$ and $\mathrm{NaAlSiO}$, respectively, that lead to decreasing of gehlenite $\left(2 \mathrm{CaO} \cdot \mathrm{Al}_{2} \mathrm{O}_{3} \cdot \mathrm{SiO}_{2}\right)$ amount with increasing of sodium sulfate addition. It should be noted that both $2 \mathrm{CaO} \cdot \mathrm{Al}_{2} \mathrm{O}_{3} \cdot \mathrm{SiO}_{2}$ and $\mathrm{NaAlSiO}_{4}$ are hardly soluble phases $[59,60]$ that can complicate following extraction of aluminum from the tailings. In the system with red mud sample U (Figure 5) high content of calcium inhibits the Reaction (5) by calcium silicate $3 \mathrm{CaO} \cdot 2 \mathrm{SiO}_{2}$ generation. As a result, $\mathrm{Na}_{2} \mathrm{O} \cdot \mathrm{Al}_{2} \mathrm{O}_{3}$ represents a single aluminum-containing phase, which is water-soluble [82], in the system with red mud sample B with addition over $23.4 \% \mathrm{Na}_{2} \mathrm{SO}_{4}$, so it seems to be more encouraging to use the raw materials with high basicity not only for iron recovery, but for the facilitation of a following aluminum extraction from the tailings.

Thus, thermodynamic calculations have shown that carbothermic roasting of both red mud samples with sodium sulfate leads to full iron metallization, but sample $\mathrm{U}$ appears to be more favorable for aluminum extraction than sample B.

\subsection{Investigation of Iron Reduction in the Roasted Samples}

Figure 6 shows the Mössbauer spectra of the samples B and $U$ roasted at $1150{ }^{\circ} \mathrm{C}$ with the addition of $\mathrm{Na}_{2} \mathrm{SO}_{4}$. Table 3 shows the parameters of the spectra.

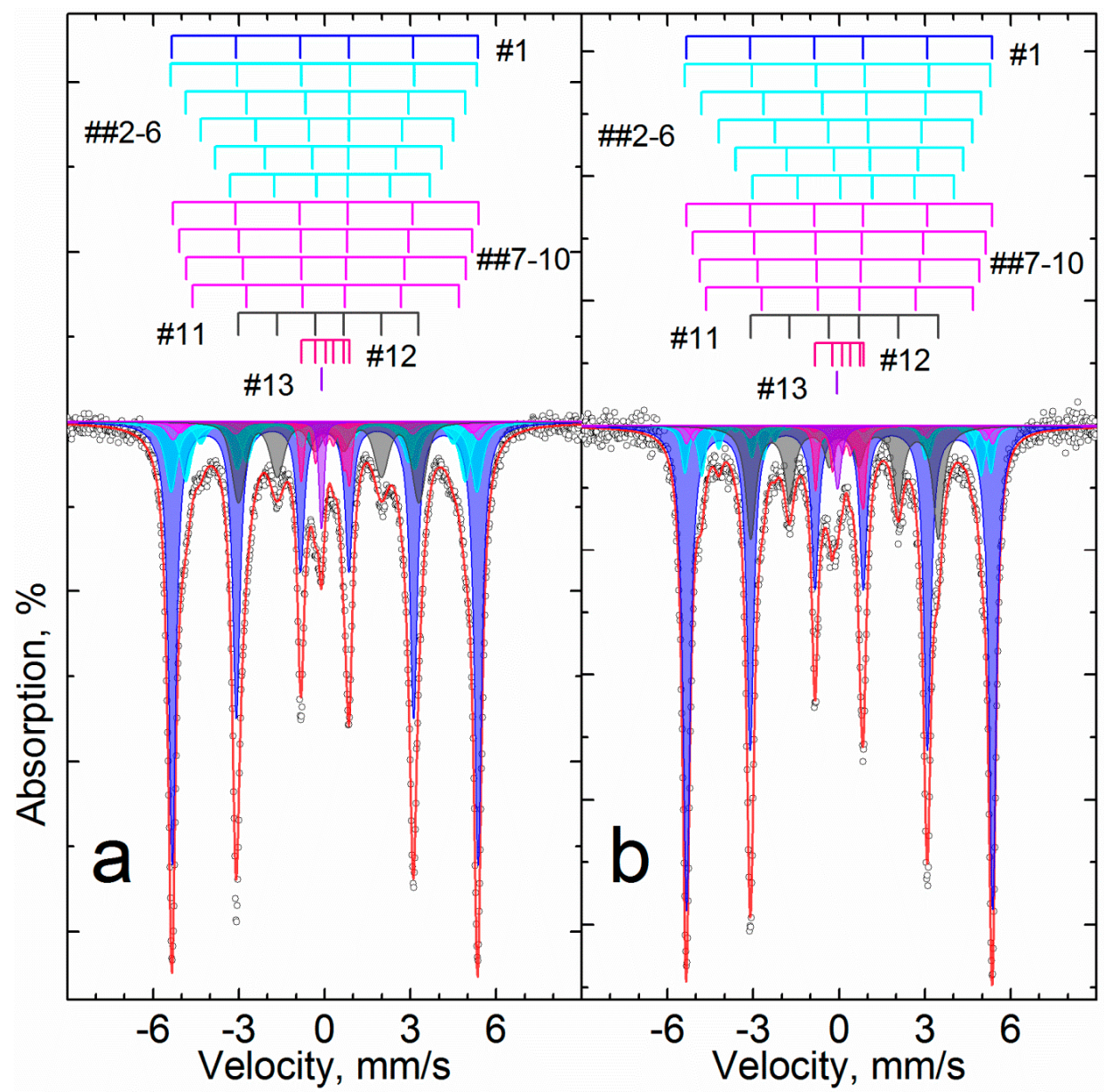

Figure 6. Mössbauer spectra obtained at $296 \mathrm{~K}$ of the roasted red mud samples U (a) and B (b) at $1150{ }^{\circ} \mathrm{C}$ during $180 \mathrm{~min}$ with addition of $13.65 \% \mathrm{Na}_{2} \mathrm{SO}_{4}$ and their model description with numbering of subspectra according to Table 3 . 
Table 3. Mössbauer spectra parameters and iron phase distribution in the roasted red mud samples $\mathrm{B}$ and $\mathrm{U}$ at $1150{ }^{\circ} \mathrm{C}$ with addition of $13.65 \% \mathrm{~N}_{\mathrm{a} 2} \mathrm{SO} \mathrm{O}_{4}$, where $\delta$ —chemical shift; $\Delta=2 \varepsilon$ —quadrupole splitting; $\Gamma_{\exp }$ —line width; $\mathrm{H}_{\text {eff }}$-hyperfine magnetic field; $\mathrm{S}$-site \# area.

\begin{tabular}{|c|c|c|c|c|c|c|c|c|c|c|c|c|c|c|c|c|c|}
\hline \multicolumn{2}{|r|}{ Sample } & \multicolumn{8}{|c|}{ Roasted B } & \multicolumn{8}{|c|}{ Roasted U } \\
\hline \multirow{2}{*}{$\#$} & \multirow{2}{*}{ Phase } & $\delta$ & $\mathrm{d} \delta$ & $\Delta=2 \varepsilon$ & $\Gamma_{\exp }$ & $\mathrm{H}_{\text {eff }}$ & $\mathrm{dH}$ & S\# & $\Sigma \mathrm{S} \#$ & $\delta$ & $\mathrm{d} \delta$ & $\Delta=2 \varepsilon$ & $\Gamma_{\exp }$ & $\mathrm{H}_{\text {eff }}$ & $\mathrm{dH}$ & S\# & $\Sigma \mathrm{S} \#$ \\
\hline & & \multicolumn{4}{|c|}{$\mathrm{mm} / \mathrm{s}$} & \multicolumn{2}{|c|}{ kOe } & \multicolumn{2}{|c|}{$\%$} & \multicolumn{4}{|c|}{$\mathrm{mm} / \mathrm{s}$} & \multicolumn{2}{|c|}{ kOe } & \multicolumn{2}{|c|}{$\%$} \\
\hline 1 & $\alpha$-Fe & 0.00 & - & 0.01 & 0.30 & 331.6 & - & 56 & 56 & 0.01 & - & 0.00 & 0.31 & 331.6 & - & 48 & 48 \\
\hline 2 & \multirow{5}{*}{$\begin{array}{c}\alpha-\mathrm{Fe}_{1-\mathrm{x}} \mathrm{A}_{x} \text {-first } \\
\text { coordination sphere }\end{array}$} & 0.00 & \multirow{5}{*}{0.14} & \multirow{5}{*}{-0.10} & \multirow{9}{*}{0.31} & 331.6 & \multirow{5}{*}{28.4} & 6 & \multirow{9}{*}{19.8} & 0.01 & \multirow{5}{*}{0.05} & \multirow{5}{*}{-0.04} & \multirow{9}{*}{0.50} & 331.6 & \multirow{5}{*}{28.7} & 12 & \\
\hline 3 & & 0.14 & & & & 303.2 & & 6.0 & & 0.06 & & & & 302.9 & & 10.4 & \\
\hline 4 & & 0.28 & & & & 274.9 & & 2.8 & & 0.12 & & & & 274.2 & & 3.8 & \\
\hline 5 & & 0.41 & & & & 247 & & 0.7 & & 0.17 & & & & 245.5 & & 0.8 & \\
\hline 6 & & 0.55 & & & & 218 & & 0.1 & & 0.22 & & & & 216.8 & & 0.1 & 33 \\
\hline 7 & \multirow{4}{*}{$\begin{array}{c}\alpha-\mathrm{Fe}_{1-x} \mathrm{~A}_{x} \text {-second } \\
\text { coordination sphere }\end{array}$} & 0.00 & \multirow{4}{*}{0.00} & \multirow{4}{*}{0.02} & & 331.6 & \multirow{4}{*}{14.2} & 2.1 & & 0.01 & \multirow{4}{*}{0.00} & \multirow{4}{*}{0.03} & & 331.6 & \multirow{4}{*}{14.3} & 3 & \\
\hline 8 & & 0.00 & & & & 303.2 & & 1.7 & & 0.01 & & & & 317.3 & & 2.0 & \\
\hline 9 & & 0.00 & & & & 289 & & 0.6 & & 0.01 & & & & 303.0 & & 0.5 & \\
\hline 10 & & 0.00 & & & & 275 & & 0.1 & & 0.01 & & & & 288.7 & & 0.1 & \\
\hline 11 & $\theta-\mathrm{Fe}_{3} \mathrm{C}$ & 0.18 & - & 0.02 & 0.42 & 203.2 & - & 18.8 & 18.8 & 0.15 & - & -0.02 & 0.57 & 195.4 & - & 13.5 & 13.5 \\
\hline 12 & Laves phase & 0.13 & - & -0.24 & 0.20 & 52.4 & - & 4.7 & 4.7 & 0.10 & - & -0.07 & 0.21 & 52.4 & - & 3.7 & 3.7 \\
\hline 13 & $\gamma$-Fe & -0.06 & - & - & 0.30 & - & - & 1.8 & 1.8 & -0.11 & - & - & 0.21 & - & - & 1.7 & 1.7 \\
\hline
\end{tabular}


The spectra consist of a broadened sextet with resonance lines slightly deformed towards the inner side and three low-intensity lines located in-between the 2-5 resonance lines of the sextet. The spectrum of the roasted sample B differs by the presence of an additional shoulder at the resonance line 5 .

It can be seen that the sextet itself corresponds to metallic iron $(\alpha-\mathrm{Fe})$ [83], and its distortion is caused by satellite subspectra of those Fe atoms in the $\alpha-\mathrm{Fe}_{1-x} \mathrm{~A}_{x}$ alloy, which neighboring 1, 2 or more Fe atoms are substituted by atoms of other metals-A [84,85]. The parameters of these subspectra are analogous to those of the subspectrum 1 (Table 3), with the only different chemical shift and effective magnetic field by $\mathrm{n} \cdot \mathrm{d} \delta$ and $-n \cdot d \mathrm{H}$, respectively, where $n$ is the number of a subspectrum, $d \delta$ and $d \mathrm{H}$ are the changes of the corresponding parameters. In this paper, a description is presented taking into account the effect on the shape of the spectra of changes in the content of iron atoms in the first (contains 8 atoms) and second (contains 6 atoms) of the nearest coordination spheres [86]. In this case, the found content of admixture atoms makes it possible to describe alloys as $\alpha-\mathrm{Fe}_{0.883} \mathrm{~A}_{0.117}$ and $\alpha-\mathrm{Fe}_{0.904} \mathrm{~A}_{0.096}$ for the roasted samples $\mathrm{B}$ and $\mathrm{U}$, respectively. The spectra of satellites with intensities less than $0.1 \%$ are not presented in the Table 3 and Figure 6 . Subspectra that describe the roasted sample $U$ have much larger width of the resonance lines than those for the roasted sample B, which indicates greater disordering of the structure.

The central resonance line in the spectra is described by a singlet (13, Table 3) of metastable FCC $\gamma$-Fe [87]. It can be seen that this polymorphic modification of iron was formed during synthesis and was stabilized by dissolved carbon with formation of the austenite-type structure [88].

Enrichment of the samples by carbon leads to formation of iron carbide like $\theta-\mathrm{Fe}_{3} \mathrm{C}, \chi-\mathrm{Fe}_{5} \mathrm{C}_{2}$ [89] and/or $\mathrm{Fe}_{7} \mathrm{C}_{3}$ [90], which is indicated by a couple of low-intensity lines between the resonance lines 2-5 and by a shoulder on the line 5 of the roasted sample $U$ in the form of internal sextet no. 11 that obviously includes combinations of several subspectra with very close super-thin parameters for the abovementioned carbides.

At last, the central part of the spectra of both samples contains a low-intensity sextet no. 12 with a small isomeric shift and very small magnetic splitting, which can relate to the Laves phases, e.g., $\mathrm{Ti}_{\mathrm{x}}(\mathrm{Fe}, \mathrm{Al})_{100-x}[91]$.

Thus, according to the Mössbauer spectra both the roasted red mud samples with the addition of $13.65 \% \mathrm{Na}_{2} \mathrm{SO}_{4}$ at $1150{ }^{\circ} \mathrm{C}$ contain no oxide or sulfide phases, but only metallic iron and its various solid solutions, so the both roasted samples can be accepted as fully reduced.

\subsection{Experimental Results of the Carbothermic Roasting Followed by Magnetic Separation}

Table 4 summarizes the possibility and particularities of the roasting and magnetic separation of the red mud samples at various temperatures and sodium sulfate addition.

Table 4. General results with signs * of the roasting and magnetic separation of the samples B and U roasted at various temperatures and $\mathrm{Na}_{2} \mathrm{SO}_{4}$ addition during $180 \mathrm{~min}$.

\begin{tabular}{|c|c|c|c|c|c|c|c|c|c|c|c|c|c|c|c|c|}
\hline \multirow{3}{*}{$\begin{array}{c}\mathrm{Na}_{2} \mathrm{SO}_{4} \\
\text { Addition, } \%\end{array}$} & \multicolumn{16}{|c|}{ Roasting Temperature $\left({ }^{\circ} \mathrm{C}\right)$ and Codename of a Sample } \\
\hline & \multicolumn{2}{|c|}{1100} & \multicolumn{2}{|c|}{1150} & \multicolumn{2}{|c|}{1200} & \multicolumn{2}{|c|}{1250} & \multicolumn{2}{|c|}{1300} & \multicolumn{2}{|c|}{1350} & \multicolumn{2}{|c|}{1400} & \multicolumn{2}{|c|}{1450} \\
\hline & B & $\mathbf{U}$ & B & $\mathbf{U}$ & B & $\mathbf{U}$ & B & $\mathbf{U}$ & B & $\mathbf{U}$ & B & $\mathbf{U}$ & B & $\mathbf{U}$ & B & $\mathbf{U}$ \\
\hline 0 & $\mathrm{n} / \mathrm{s}$ & $\mathrm{n} / \mathrm{s}$ & $\mathrm{n} / \mathrm{s}$ & $\mathrm{n} / \mathrm{s}$ & $\mathrm{n} / \mathrm{s}$ & $\mathrm{n} / \mathrm{s}$ &,$+ \mathrm{m}$ & $\mathrm{n} / \mathrm{s}$ &,$+ \mathrm{m}$ & $\mathrm{n} / \mathrm{s}$ & $\mathrm{fm}$ & $\mathrm{n} / \mathrm{s}$ & $\mathrm{fm}$ & + & $\mathrm{fm}$ & $\mathrm{fm}$ \\
\hline 4.55 & $\mathrm{n} / \mathrm{s}$ & $\mathrm{n} / \mathrm{s}$ & $\mathrm{n} / \mathrm{s}$ & $\mathrm{n} / \mathrm{s}$ & $\mathrm{n} / \mathrm{s}$ & $\mathrm{n} / \mathrm{s}$ &,$+ \mathrm{m}$ & $\mathrm{n} / \mathrm{s}$ &,$+ \mathrm{m}$ & $\mathrm{n} / \mathrm{s}$ & $\mathrm{fm}$ & - & $\mathrm{fm}$ & - & $\mathrm{fm}$ & $\mathrm{fm}$ \\
\hline 13.65 & $\mathrm{n} / \mathrm{s}$ & $\mathrm{n} / \mathrm{s}$ & + & $\mathrm{n} / \mathrm{s}$ & + & $\mathrm{n} / \mathrm{s}$ &,$+ \mathrm{m}$ & $\mathrm{n} / \mathrm{s}$ &,$+ \mathrm{m}$ & $\mathrm{n} / \mathrm{s}$ & $\mathrm{fm}$ & + & $\mathrm{fm}$ & + & $\mathrm{fm}$ & $\mathrm{fm}$ \\
\hline 18.2 & $\mathrm{n} / \mathrm{s}$ & $\mathrm{n} / \mathrm{s}$ & + & $\mathrm{n} / \mathrm{s}$ & + & $\mathrm{n} / \mathrm{s}$ &,$+ \mathrm{m}$ & $\mathrm{n} / \mathrm{s}$ &,$+ \mathrm{m}$ & $\mathrm{n} / \mathrm{s}$ & $\mathrm{fm}$ & - & $\mathrm{fm}$ & - & $\mathrm{fm}$ & $\mathrm{fm}$ \\
\hline 22.75 & $\mathrm{n} / \mathrm{s}$ & $\mathrm{n} / \mathrm{s}$ & + & $\mathrm{n} / \mathrm{s}$ & + & $\mathrm{n} / \mathrm{s}$ &,$+ \mathrm{m}$ & $\mathrm{n} / \mathrm{s}$ &,$+ \mathrm{m}$ & $\mathrm{n} / \mathrm{s}$ & $\mathrm{fm}$ & - & $\mathrm{fm}$ & - & $\mathrm{fm}$ & $\mathrm{fm}$ \\
\hline 27.3 & $\mathrm{n} / \mathrm{s}$ & $\mathrm{n} / \mathrm{s}$ & + & $\mathrm{n} / \mathrm{s}$ & + & $\mathrm{n} / \mathrm{s}$ &,$+ \mathrm{m}$ & $\mathrm{n} / \mathrm{s}$ &,$+ \mathrm{m}$ & $\mathrm{n} / \mathrm{s}$ & $\mathrm{fm}$ & + & $\mathrm{fm}$ & + & $\mathrm{fm}$ & $\mathrm{fm}$ \\
\hline
\end{tabular}

* "+"-successful separation; " $\mathrm{n} / \mathrm{s}$ "—no separation or insignificant separation with yield of tailings $<5 \%$; " $\mathrm{m}$ " — clear melting effects after the roasting such as obvious change of initial form and aggregation of the tablets; fm-melting accompanied by coalescence of the tablets and flow of the sample through graphite layer from the crucible. 
It can be seen that the results are quite different for the samples B and U. Melting without or with any addition of sodium sulfate in the samples $B$ and $U$ occurred above $1300^{\circ} \mathrm{C}$ and $1400^{\circ} \mathrm{C}$, respectively, that led to obtaining of an almost molten and uniform sample, so these conditions are undesirable and unrelated to solid-phase carbothermic reduction process. The separation of the samples without addition is possible at $1250-1300{ }^{\circ} \mathrm{C}$ and $1400{ }^{\circ} \mathrm{C}$, while the addition of $13.65 \% \mathrm{Na}_{2} \mathrm{SO}_{4}$ and over expands the separation range to $1150-1300{ }^{\circ} \mathrm{C}$ and $1350-1400{ }^{\circ} \mathrm{C}$ for the samples $\mathrm{B}$ and $\mathrm{U}$, respectively. Below these temperatures it is impossible to extract a significant amount of non-magnetic tailings.

To elucidate the obtained results, the iron grain growth process was studied. Figure 7 compares the influence of addition of $13.65 \% \mathrm{Na}_{2} \mathrm{SO}_{4}$ on iron grain growth at constant holding time in the range of $1000-1300{ }^{\circ} \mathrm{C}$ to red mud B and $\mathrm{U}$.

The histograms show that at the range of $1000-1100{ }^{\circ} \mathrm{C}$ iron particles are mainly distributed between fractions of $1-20 \mu \mathrm{m}$ in size (Figure $7 \mathrm{a}, \mathrm{b}$ ). There is a small amount of iron grains larger than $40 \mu \mathrm{m}$ in the samples of roasted red mud $\mathrm{U}$ in contrast with red mud B obtained in the similar conditions. An increase of the roasting temperature to $1150-1200{ }^{\circ} \mathrm{C}$ (Figure $7 \mathrm{c}, \mathrm{d}$ ) led to an increase of the grain size in the sample $\mathrm{B}$ with addition of $13.65 \% \mathrm{Na}_{2} \mathrm{SO}_{4}$, where the relative area of iron grains with a size larger $40 \mu \mathrm{m}$ was more than $50 \%$. It should be noted that in the sample $\mathrm{U}$ grains of the fraction larger $40 \mu \mathrm{m}$ have the relative area about 10-20\% under the same conditions. Further rise of the roasting temperature to $1250-1300{ }^{\circ} \mathrm{C}$ (Figure 7e,f) caused a significant growth of iron grains for the sample $\mathrm{B}$ both with and without sodium sulfate addition, where the relative area of iron grains with a size larger $40 \mu \mathrm{m}$ is more than $85 \%$. For the sample $U$ roasted at these temperatures the addition of $13.65 \% \mathrm{Na}_{2} \mathrm{SO}_{4}$ considerably increased the relative area of iron grains with a size larger $40 \mu \mathrm{m}$, but it is still half as much as in the sample B.

To find out optimal conditions for the roasting of red mud $\mathrm{U}$, we raised the roasting temperature additionally. Figure 8 demonstrates the distribution of the iron grain fractions at $1350-1400{ }^{\circ} \mathrm{C}$ with and without $\mathrm{Na}_{2} \mathrm{SO}_{4}$.

It can be seen that, at $1350{ }^{\circ} \mathrm{C}$, the relative area of iron grains larger than $40 \mu \mathrm{m}$ is more than $60 \%$ and $25 \%$ in the samples with and without addition of sodium sulfate, respectively, while at $1400{ }^{\circ} \mathrm{C}$ it is in the range of $73-84 \%$.

Thus, iron grain size calculations (Figures 7 and 8) correlate with the general magnetic separation results (Table 4). Based on the data comparison, it can be inferred that the main part of iron grains larger than $40 \mu \mathrm{m}$ predetermines successful magnetic separation of the roasted samples.

Figure 9 demonstrates the magnetic separation indexes of the roasted sample B with addition of 13.65-27.3\% $\mathrm{Na}_{2} \mathrm{SO}_{4}$ at $1150-1300{ }^{\circ} \mathrm{C}$; Figure 10 illustrates the microstructure of the roasted sample $\mathrm{B}$ obtained at $1150-1200{ }^{\circ} \mathrm{C}$ with varied amount of the additive.

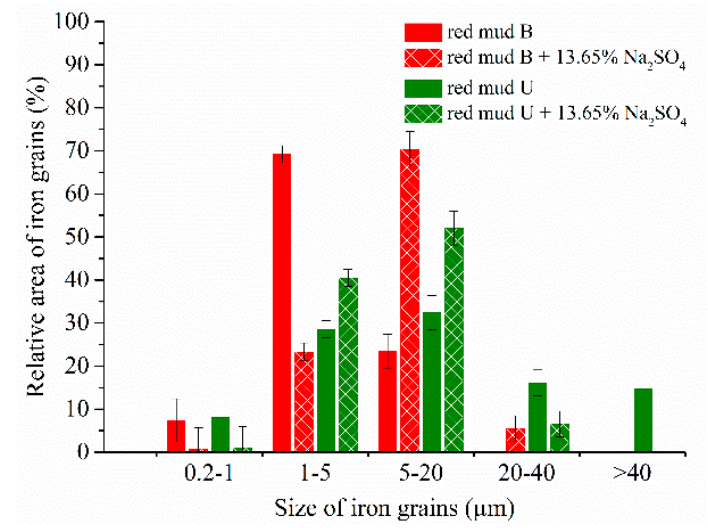

(a)

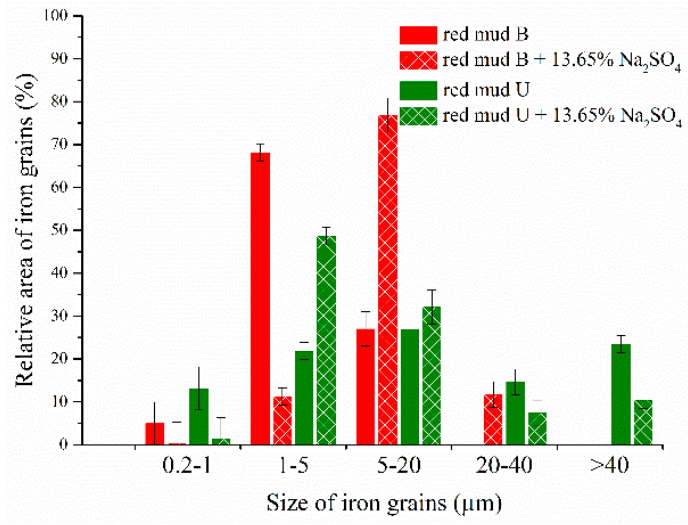

(b)

Figure 7. Cont. 


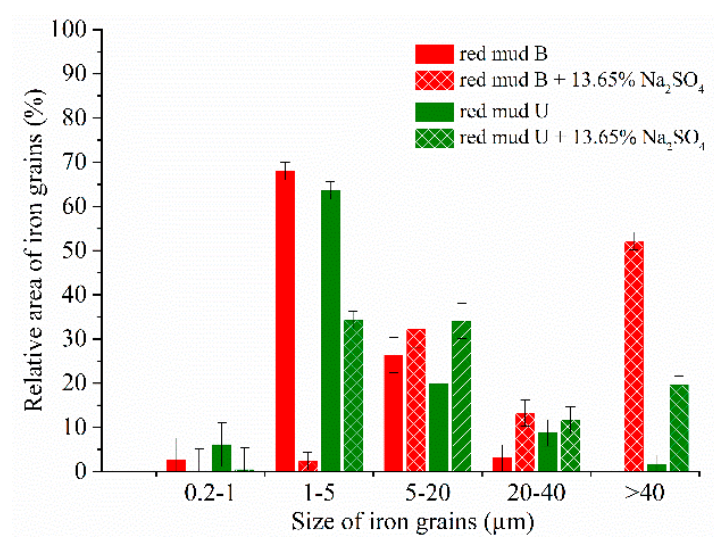

(c)

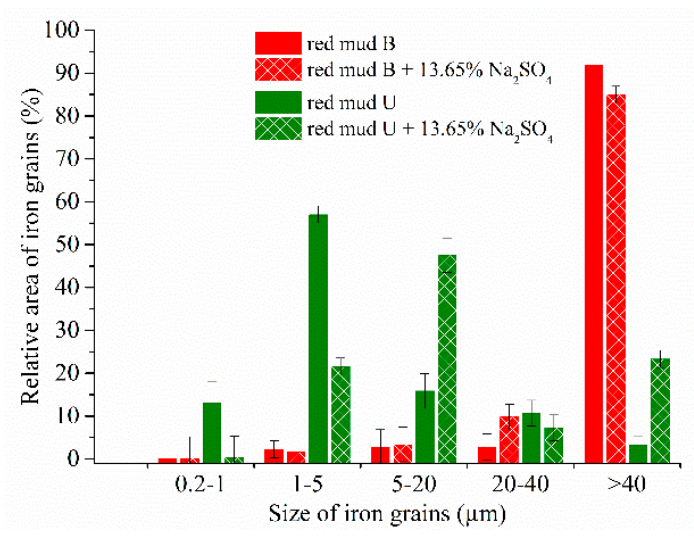

(e)

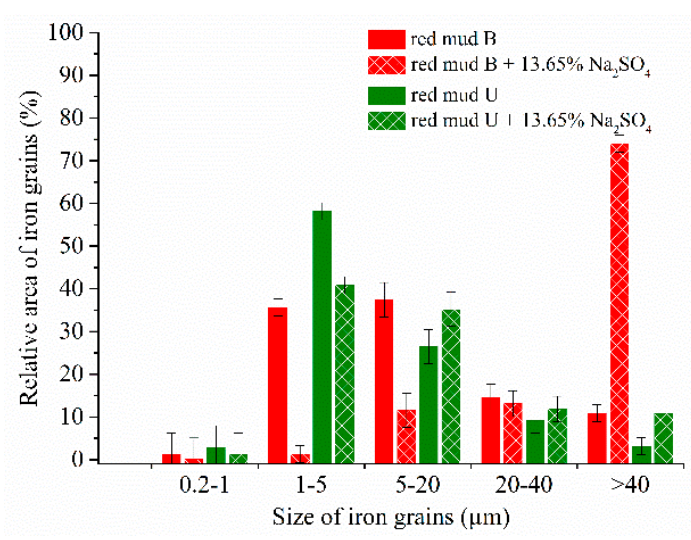

(d)

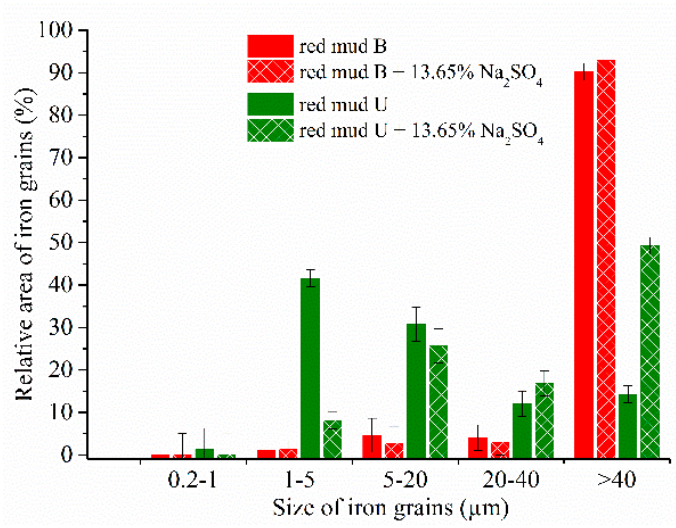

(f)

Figure 7. Effect of $13.65 \% \mathrm{Na}_{2} \mathrm{SO}_{4}$ addition to the samples $\mathrm{B}$ and $\mathrm{U}$ on the relative area of iron grains of different fractions after $180 \mathrm{~min}$ of roasting at $100{ }^{\circ} \mathrm{C}(\mathbf{a}), 1100{ }^{\circ} \mathrm{C}(\mathbf{b}), 1150{ }^{\circ} \mathrm{C}(\mathbf{c}), 1200{ }^{\circ} \mathrm{C}(\mathbf{d}), 1250{ }^{\circ} \mathrm{C}(\mathbf{e})$, $1300{ }^{\circ} \mathrm{C}(\mathbf{f})$.

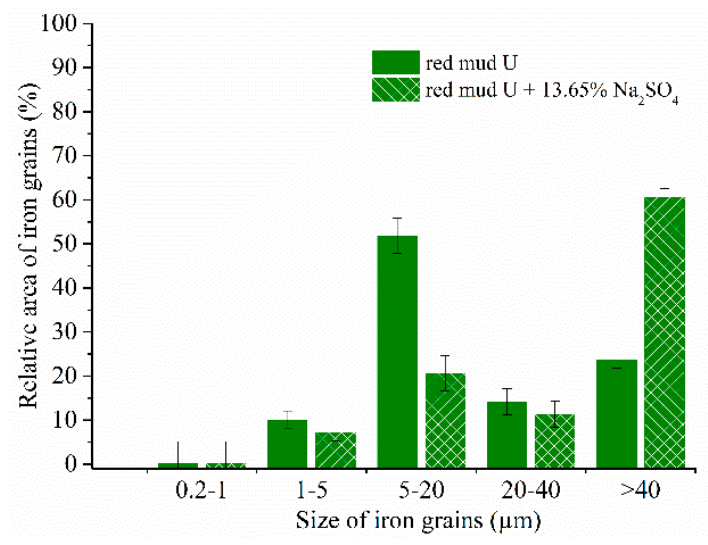

(a)

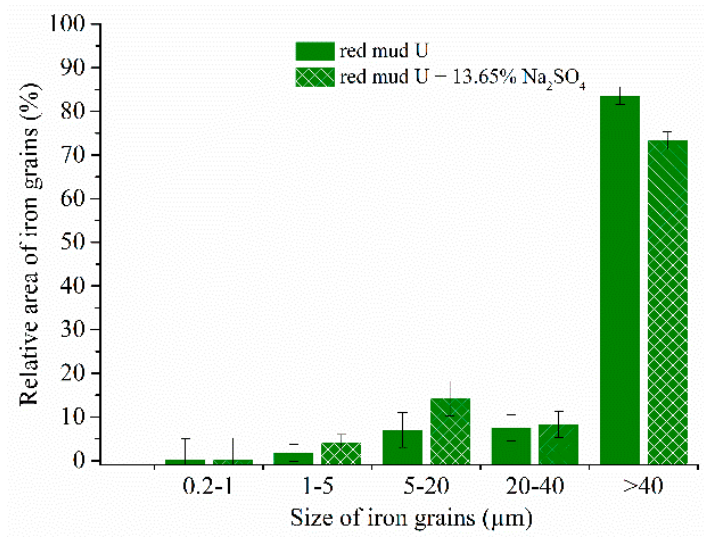

(b)

Figure 8. Effect of $13.65 \% \mathrm{Na}_{2} \mathrm{SO}_{4}$ addition to the red mud sample $\mathrm{U}$ on the relative area of iron grains of different fractions after $180 \mathrm{~min}$ of roasting at $1350{ }^{\circ} \mathrm{C}(\mathbf{a})$ and $1400{ }^{\circ} \mathrm{C}(\mathbf{b})$. 

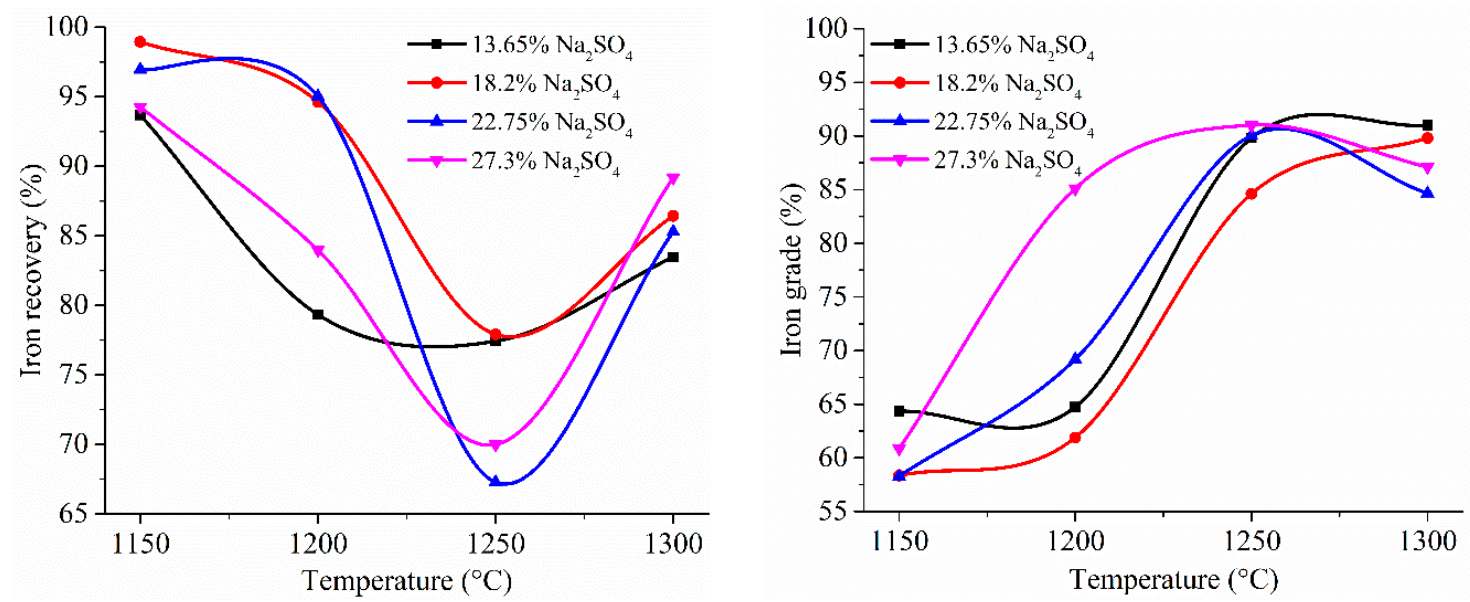

Figure 9. Effect of the roasting temperature on iron recovery (a) and iron grade of magnetic concentrate (b) of the sample B roasted during $180 \mathrm{~min}$.
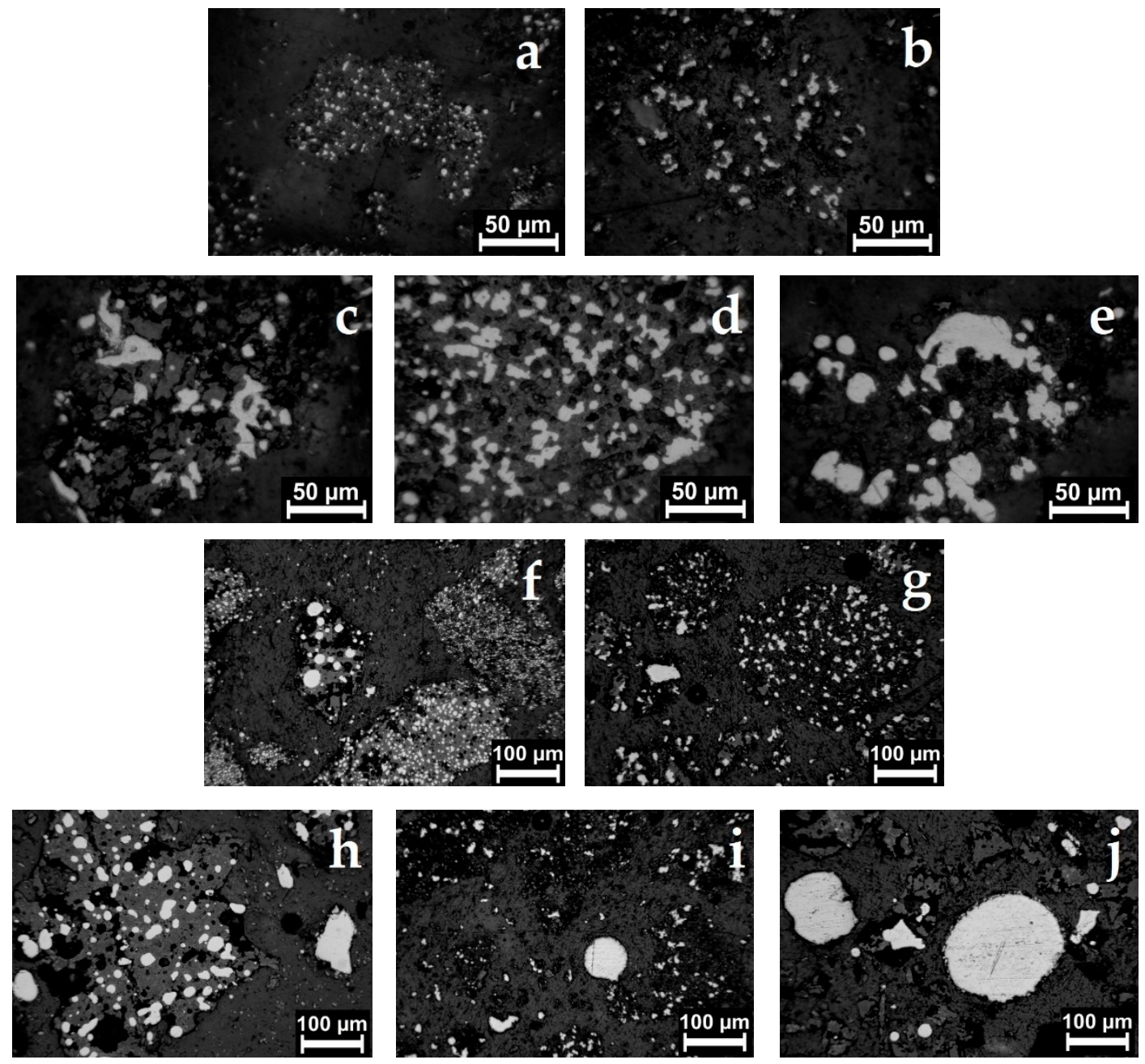

Figure 10. The microstructure of the red mud sample B after the carbothermic roasting during $180 \mathrm{~min}$ without addition (a), and with addition of $9.1 \%(\mathbf{b}), 13.65 \%$ (c), $18.2 \%(\mathbf{d}), 27.3 \%(\mathbf{e}) \mathrm{Na}_{2} \mathrm{SO}_{4}$ at $1150{ }^{\circ} \mathrm{C}$; without addition (f), and with addition of $9.1 \%(\mathbf{g}), 13.65 \%(\mathbf{h}), 18.2 \%(\mathbf{i}), 27.3 \%(\mathbf{j}) \mathrm{Na}_{2} \mathrm{SO}_{4}$ at $1200{ }^{\circ} \mathrm{C}$.

Figure 9a,b demonstrate that both iron recovery and iron grade dependences are rather sigmoid. The micrographs (Figure 10) clarify the process of iron grain growth at $1150-1200{ }^{\circ} \mathrm{C}$, where the $\mathrm{Na}_{2} \mathrm{SO}_{4}$ addition contributed to increase the grain size. The iron particles up to $13.65 \% \mathrm{Na}_{2} \mathrm{SO}_{4}$ addition have 
a small size and strongly attached to the gangue phase, so no separation occurred in the samples obtained at $1150-1200{ }^{\circ} \mathrm{C}$, while the separation of the samples over $13.65 \% \mathrm{Na}_{2} \mathrm{SO}_{4}$ addition at these temperature range leads to high iron recovery rates, but low grades of the magnetic concentrates. Besides the majority of iron grains, which are larger than $40 \mu \mathrm{m}$, the samples roasted at $1150-1200{ }^{\circ} \mathrm{C}$ contain a significant percentage of the grains $5-40 \mu \mathrm{m}$ in size (Figure 7c,d). Probably, the aggregates of iron grains of such size with gangue are unable to split apart during grinding process that decrease the iron concentrate grade. Apparently, decreasing of iron recovery and increasing of iron grade at the range of $1150-1250^{\circ} \mathrm{C}$ are due to a growing proportion of the molten phase during the roasting. On the one hand, the liquid phase promotes diffusion and aggregation of iron metallic particles [92] that enhances gangue-grain release during grinding and accordingly increases iron grade of the concentrate after magnetic separation. On the other hand, it is complicated to separate magnetically besides large iron particles also the grains of small and middle size attached to gangue from difficult to grind semi-molten material after solidification that results to decreasing of iron recovery. It can be seen from Figure 9a that the temperature dependence of iron recovery has a minimum at $1250{ }^{\circ} \mathrm{C}$ with the addition of $18.2-27.3 \% \mathrm{Na}_{2} \mathrm{SO}_{4}$ that can be explained by attaching of iron grains with size less than $40 \mu \mathrm{m}$ (see Figure 7e) to the gangue phase in the presence of a substantial amount of liquid phase (see Table 4). An increase in iron recovery at $1300{ }^{\circ} \mathrm{C}$ is likely due to an increase of the iron grain growth rate and decrease in the proportion of the small grains.

Figure 11 shows the influence of sodium sulfate addition on the magnetic separation indexes of the sample B roasted at $1250^{\circ} \mathrm{C}$ and $1300{ }^{\circ} \mathrm{C}$.

The obtained curves indicate that closely to the melting point at $1250^{\circ} \mathrm{C}$ and $1300^{\circ} \mathrm{C}$ the mechanism of the iron grain growth and extraction is different probably due to a different liquid phase content. In general, the cumulative evidence suggests that at these conditions sodium sulfate addition leads to approximately equal or lower iron recovery and iron grade.

To study in more detail a behavior of different phases during the roasting and magnetic separation, $\mathrm{XRD}$ analysis was carried out. Figure 12 shows the XRD patterns of non-magnetic fraction of the samples with maximum temperature before full melting and maximum $\mathrm{Na}_{2} \mathrm{SO}_{4}$ addition.

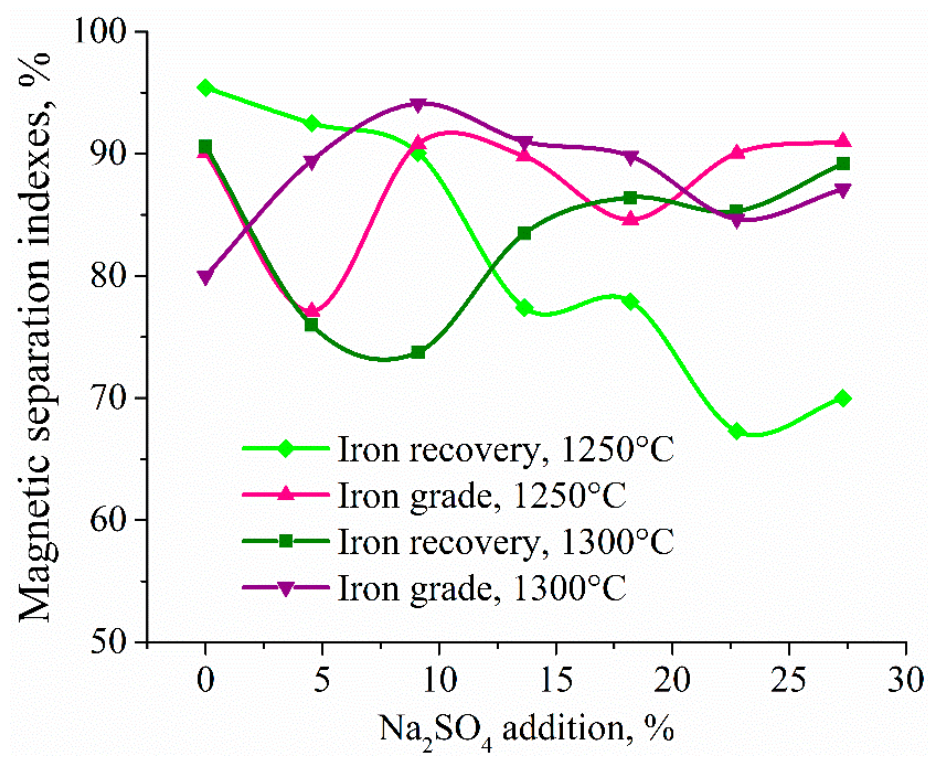

Figure 11. Effect of the $\mathrm{Na}_{2} \mathrm{SO}_{4}$ addition to the red mud sample $\mathrm{B}$ roasted at $1250-1300{ }^{\circ} \mathrm{C}$ during $180 \mathrm{~min}$ on iron recovery and grade of magnetic concentrate.

The XRD patterns points out that the main phases of both samples are melilite $\mathrm{CaNaAlSi}_{2} \mathrm{O}_{7}$, oldhamite $\mathrm{CaS}$, unextracted metallic iron and sodium sulfide $\mathrm{Na}_{2} \mathrm{~S}$. Therefore, there are no the Reactions (4) and (5) at these conditions. Amorphous halo is also present in the both samples due to high content of a liquid phase uncrystallized during the quenching in liquid nitrogen. Furthermore, 
it is interesting to note that the tailings obtained from the sample B contain insignificant amount of FeS, while it was not detected in the tailings obtained from the sample $U$. This fact indicates that the roasting of the sample B with a lack of calcium to generate calcium sulfide forms not only $\mathrm{Na}_{2} \mathrm{~S}$ according to thermodynamic calculations (Figure 4), but also FeS.

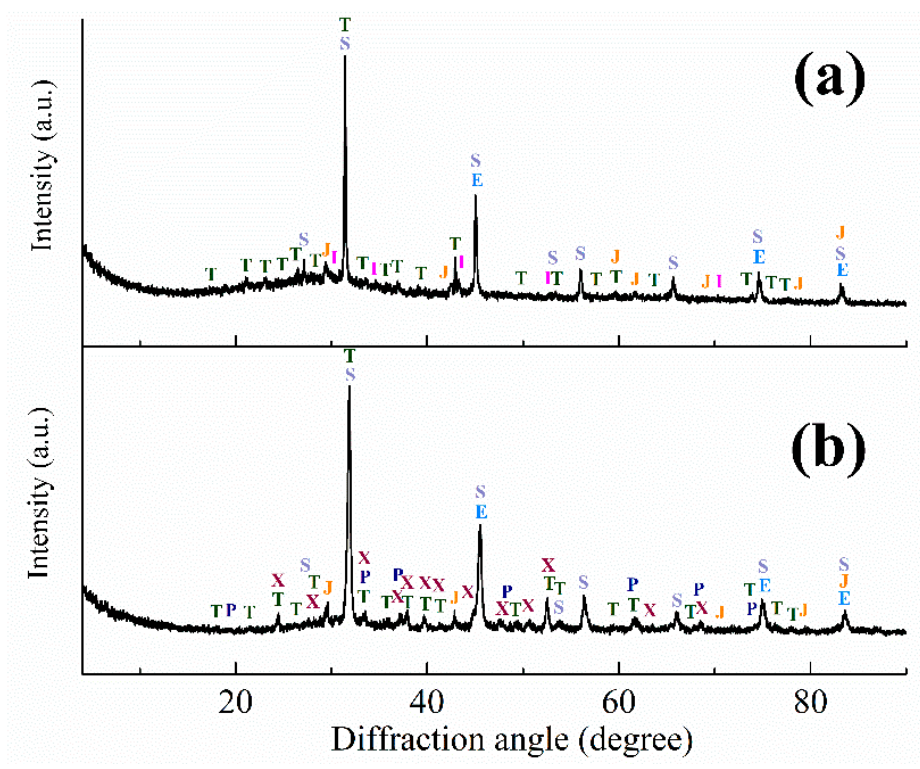

Figure 12. XRD patterns of the tailings obtained by roasting of red mud B at $1300{ }^{\circ} \mathrm{C}$ (a) and red mud $\mathrm{U}$ at $1400{ }^{\circ} \mathrm{C}(\mathbf{b})$ with $27.3 \% \mathrm{Na}_{2} \mathrm{SO}_{4}$ and 180 min duration time and following magnetic separation, where S-CaS; T- $\mathrm{CaNaAlSi}_{2} \mathrm{O}_{7} ; \mathrm{X}-\mathrm{Ca}_{2} \mathrm{Al}_{2} \mathrm{SiO}_{7} ; \mathrm{J}-\mathrm{Na}_{2} \mathrm{~S} ; \mathrm{P}-\mathrm{CaTiO}_{3} ; \mathrm{E}-\alpha-\mathrm{Fe} ; \mathrm{I}-\mathrm{FeS}$ (troilite).

Figure 13 shows the influence of holding time on the magnetic separation indexes (a) and distribution of the iron grain fractions in it (b) at fixed temperature and $\mathrm{Na}_{2} \mathrm{SO}_{4}$ addition after roasting of the sample B.

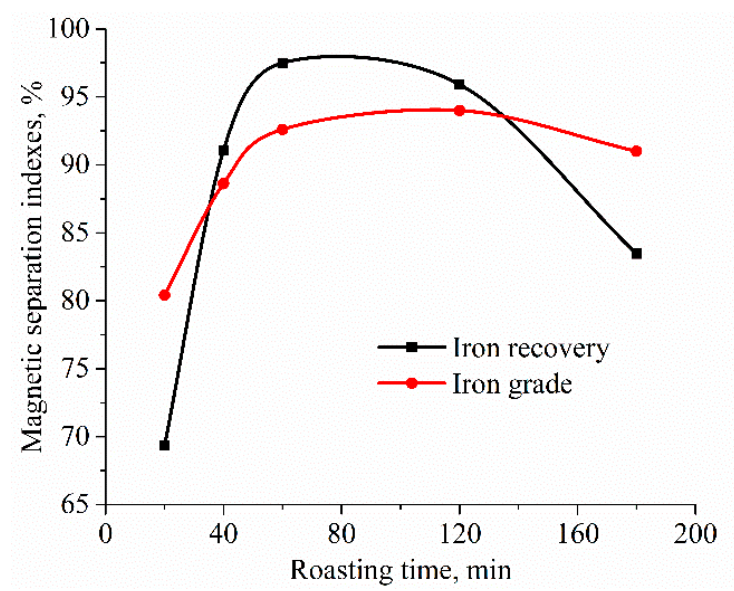

(a)

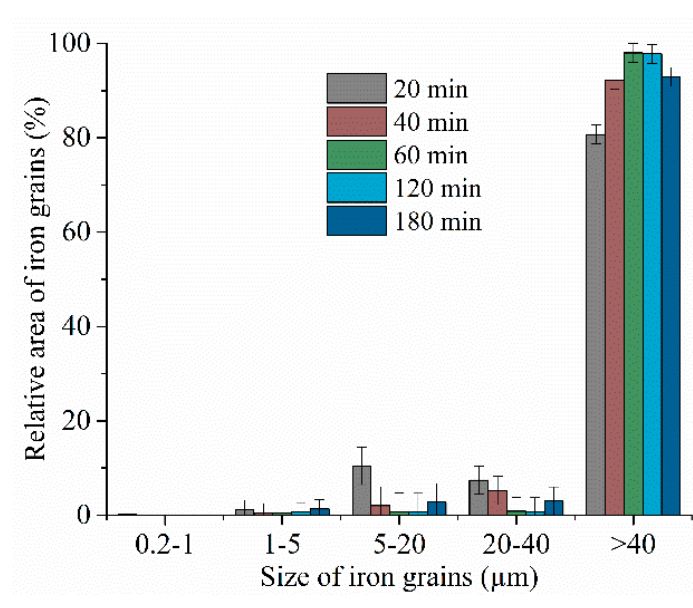

(b)

Figure 13. Effect of the roasting time on magnetic separation indexes (a) and the relative area of iron grains of different fractions (b) of the red mud sample $\mathrm{B}$ with addition of $13.65 \% \mathrm{Na}_{2} \mathrm{SO}_{4}$ roasted at $1300{ }^{\circ} \mathrm{C}$.

As reflected by Figure 13a, the magnetic separation indexes rise, reach a peak, then drop. Analogous time dependences were obtained in other studies on carbothermic roasting of red mud $[41,47,49,93,94]$. It is clear from the obtained data that iron recovery and iron grade correlate well with the size distribution of iron grains, so the crucial factor of Fe extraction is the iron grain size. The optimal 
roasting time for $1300{ }^{\circ} \mathrm{C}$ with the addition of $13.65 \% \mathrm{Na}_{2} \mathrm{SO}_{4}$ is $60 \mathrm{~min}$, where iron recovery and iron grade were $97.5 \%$ and $92.6 \%$, respectively.

Table 5 shows the results of magnetic separation of the roasted sample $U$.

Table 5. The magnetic separation indexes of the reduced samples $\mathrm{U}$ with $\mathrm{Na}_{2} \mathrm{SO}_{4}$ addition.

\begin{tabular}{cccc}
\hline Temperature, ${ }^{\circ} \mathrm{C}$ & Addition & Iron Recovery $(\varepsilon), \%$ & Iron Grade $\left(\% F \boldsymbol{e}_{\boldsymbol{c}}\right), \%$ \\
\hline \multirow{2}{*}{$1350{ }^{\circ} \mathrm{C}$} & $13.65 \% \mathrm{Na}_{2} \mathrm{SO}_{4}$ & 83.91 & 83.7 \\
& $27.3 \% \mathrm{Na}_{2} \mathrm{SO}_{4}$ & 87.21 & 51.6 \\
\hline \multirow{3}{*}{$1400{ }^{\circ} \mathrm{C}$} & Without addition & 82.83 & 83.6 \\
& $13.65 \% \mathrm{Na}_{2} \mathrm{SO}_{4}$ & 86.09 & 78.3 \\
& $27.3 \% \mathrm{Na}_{2} \mathrm{SO}_{4}$ & 89.08 & 82.7 \\
\hline
\end{tabular}

The data demonstrate that the grade of iron concentrate obtained by roasting of the red mud $U$ at $1350{ }^{\circ} \mathrm{C}$ is inferior to even the grade of the roasted red mud B at $1150{ }^{\circ} \mathrm{C}$ (Figure 9b). An increase of the roasting temperature up to $1400^{\circ} \mathrm{C}$ improves the grade of iron concentrate, but iron content is still low compared, for example, with the concentrate obtained from the roasted red mud B at $1250{ }^{\circ} \mathrm{C}$.

In general, the temperature range of successful separation of the roasted samples $U$ is narrower than that of the roasted samples B. Thus, obtaining of separated samples only at $1350-1400{ }^{\circ} \mathrm{C}$ near melting point indicates that high basicity is undesirable for iron extraction in spite of favorable thermodynamic conditions (Figure 5).

Table 6 compares the contents of iron, carbon, sulfur and phosphorus in the iron concentrates, obtained by the treatment of the sample B with and without sodium sulfate addition.

Table 6. Chemical composition (wt.\%) of the concentrates obtained by roasting of the red mud B at $1250{ }^{\circ} \mathrm{C}$ and $180 \mathrm{~min}$ duration time without additions and with addition of $9.1 \% \mathrm{Na}_{2} \mathrm{SO}_{4}$ and following magnetic separation.

\begin{tabular}{|c|c|c|c|c|}
\hline Addition & $\mathbf{F e}$ & $\mathrm{C}$ & $S$ & $\mathbf{P}$ \\
\hline- & 90.06 & 1.27 & 0.23 & 0.80 \\
\hline $9.1 \% \mathrm{Na}_{2} \mathrm{SO}_{4}$ & 90.80 & 1.60 & 1.16 & 0.88 \\
\hline
\end{tabular}

It is well known that the conventional content of carbon in direct-reduced iron for steelmaking is $1-2.5 \%$ [95], and the obtained concentrates comply with this range. Phosphorus content in both concentrates is almost similar, but sulfur content differs. A significant sulfur content is in the concentrate obtained with $9.1 \% \mathrm{Na}_{2} \mathrm{SO}_{4}$ addition compared with another one. This fact shows that $\mathrm{Na}_{2} \mathrm{SO}_{4}$ addition in the amount of $9.1 \%$ leads to a considerable increase of sulfur content in the concentrate although the thermodynamic calculation at such amount of sodium sulfate has indicated the presence only non-magnetic CaS (Figure 4). Moreover, the investigation of iron phase distribution in the roasted samples with addition of $13.65 \% \mathrm{Na}_{2} \mathrm{SO}_{4}$ by Mössbauer spectroscopy (Figure 6 and Table 3) detected no iron-sulfur-containing phases. Hence, a small part of gangue including sulfur-containing compounds attaches with iron grains, thereby deteriorating purity and grade of the concentrate.

\section{Discussion}

The experimental results have shown that the basicity of red mud has a significant influence on the iron grain growth during carbothermic reduction of red mud. A large amount of $\mathrm{CaO}$ in red mud composition leads to the formation of minerals with high melting temperature such as $\mathrm{Ca}_{2} \mathrm{Al}_{2} \mathrm{SiO}_{7}$ (Figure 12b) that inhibits the process of iron grain growth. The addition of alkali metal salts decreases a melting point of the sample that promotes growth of metallic particles [46,92].

Based on the present study, one might assume that sodium sulfate has an ambivalent effect on iron grain growth process in the case of carbothermic reduction of the red mud samples with high 
content of $\mathrm{CaO}+\mathrm{Al}_{2} \mathrm{O}_{3}$ compared with $\mathrm{SiO}_{2}$. On the one hand, $\mathrm{Na}_{2} \mathrm{SO}_{4}$ reacts with $\mathrm{CaO}$ and $\mathrm{Al}_{2} \mathrm{O}_{3}$ with the formation of $\mathrm{CaNaAlSi}_{2} \mathrm{O}_{7}$ with low melting point, thereby facilitating the growth of iron particles. On the other hand, CaS with high melting point also forms (Figure 12), which in some degree decreases the liquid phase amount.

In contrast with $\mathrm{Na}_{2} \mathrm{CO}_{3}$ addition for carbothermic roasting of the red mud sample $\mathrm{U}$ at $1300{ }^{\circ} \mathrm{C}$ for $180 \mathrm{~min}$ [48], the roasting of the same red mud sample with $\mathrm{Na}_{2} \mathrm{SO}_{4}$ under similar conditions resulted in negligible separation of iron from gangue. Increasing temperature up to $1350{ }^{\circ} \mathrm{C}$ led to iron separation into concentrate with a worse grade compared with the grade of the concentrate obtained after roasting with $\mathrm{Na}_{2} \mathrm{CO}_{3}$ addition at $1300^{\circ} \mathrm{C}$. Therefore, it can be inferred that the $\mathrm{Na}_{2} \mathrm{CO}_{3}$ addition is more preferable compared with the $\mathrm{Na}_{2} \mathrm{SO}_{4}$ addition for iron extraction from red mud with higher basicity.

Iron separates from the red mud B after roasting at lower temperature and amount of the additive compared with the red mud U. Iron recovery of $97 \%$ and iron concentrate grade of $64.9 \%$ were obtained after roasting at $1150{ }^{\circ} \mathrm{C}$ and with addition of $13.65 \% \mathrm{Na}_{2} \mathrm{SO}_{4}$ that agrees well with previously reported red mud roasting with similar basicity in the presence of sodium sulfate $[39,46]$. It should be noted that iron content in the concentrate may be higher in the case of the application of wet magnetic separation, which is more suitable for finely ground materials [96].

As a generalization, the following mechanism of sodium sulfate influence on iron grain growth during carbothermic roasting of red mud with different basicity is suggested. As mentioned above, an increase of the $\mathrm{Na}_{2} \mathrm{SO}_{4}$ amount increases the liquid phase proportion, which promotes diffusion and aggregation of reduced iron particles. At excess of sulfur with respect to calcium to form CaS, an additional factor has a significant effect due to FeS formation by the following reactions [81]:

$$
\begin{gathered}
\mathrm{Na}_{2} \mathrm{SO}_{4}+3 \mathrm{CO}_{(\mathrm{g})}=\mathrm{Na}_{2} \mathrm{O}+3 \mathrm{CO}_{2(\mathrm{~g})}+\mathrm{S}_{(\mathrm{g})} \\
\mathrm{Fe}+\mathrm{S}_{(\mathrm{g})}=\mathrm{FeS}
\end{gathered}
$$

The formation of FeS at the grain edges decreases surface tension and significantly promotes iron grain growth [97] that facilitates iron separation and grade of the concentrate. Probably, this factor predetermined the better effect on iron grain growth of sodium sulfate compared with other additives [57]. However, $\mathrm{FeS}$ is antiferromagnetic compound [98], so further increase of $\mathrm{Na}_{2} \mathrm{SO}_{4}$ leads to a decrease of iron recovery [99].

Thus, the effect of the sodium sulfate addition can be beneficial for nickel extraction, which is more valuable than iron, during the processing of complex ores [97], but it is inefficient for only iron recovery, especially from materials with a high content of calcium like the red mud samples $B$ and $U$. Formation of calcium sulfide with a high melting point and deterioration of the concentrate quality by sulfur impurity (see Table 6) indicates that the $\mathrm{Na}_{2} \mathrm{SO}_{4}$ addition is unsuitable for the red mud carbothermic roasting, and it is more favorable to use other additives, e.g., $\mathrm{Na}_{2} \mathrm{CO}_{3}$.

However, whatever additive was used in the carbothermic roasting, low iron content in the tailings is favorable for their following leaching because high iron content hinders the extraction of scandium from leached solutions [100]. In addition, it was shown that $\mathrm{Na}_{2} \mathrm{CO}_{3}$ and $\mathrm{Na}_{2} \mathrm{SO}_{4}$ additions for carbothermic roasting of red mud promote recovery of valuable components from the tailings into solution using sulfuric acid leaching [42]. Therefore, the alkaline additions not only improve iron recovery after the roasting of red mud, but enable subsequent treatment of tailings by hydrometallurgical methods.

\section{Conclusions}

Experimental investigation of iron grain growth during carbothermic reduction of red mud with different basicity in the presence of $\mathrm{Na}_{2} \mathrm{SO}_{4}$ has enabled to determine optimal roasting conditions. The roasting during $180 \mathrm{~min}$ with addition of $13.65 \% \mathrm{Na}_{2} \mathrm{SO}_{4}$ at $1350{ }^{\circ} \mathrm{C}$ and $1150{ }^{\circ} \mathrm{C}$ followed by magnetic separation resulted in obtaining of iron concentrates with $83.91 \%$ and $97 \%$ of iron recovery, $83.7 \%$ and $64.9 \%$ of iron grade for the red mud samples $\mathrm{U}$ and $\mathrm{B}$, respectively. In the absence of $\mathrm{Na}_{2} \mathrm{SO}_{4}$ 
there was no successful separation for the red mud $U$, while the best results for the red mud B were iron recovery of $95.42 \%$ and iron grade of $90.06 \%$ obtained by roasting during $180 \mathrm{~min}$ at $1250{ }^{\circ} \mathrm{C}$. Although the concentrate obtained after roasting of the red mud B with addition of $13.65 \% \mathrm{Na}_{2} \mathrm{SO}_{4}$ at $1150{ }^{\circ} \mathrm{C}$ has a lower content of iron compared to the concentrates obtained at $1250-1300{ }^{\circ} \mathrm{C}$ with and without $\mathrm{Na}_{2} \mathrm{SO}_{4}$ addition, a significant decrease of the roasting temperature and better grindability due to the absence of melting effects can be more beneficial for practical application. However, it has to be taken into account that the $\mathrm{Na}_{2} \mathrm{SO}_{4}$ addition leads to an increase of sulfur content in the concentrate and slightly inhibits the iron grain growth process due to calcium sulfide formation, so other alkaline sulfur-free additives are more suitable to improve carbothermic roasting of red mud.

Author Contributions: Funding acquisition, A.P.; investigation, P.G., D.Z., D.P., A.S., M.P. and A.Z.; methodology, P.G., D.Z., and D.P.; project administration, V.D.; resources, V.D.; software, P.G. and D.P.; writing, original draft, P.G., D.Z., and D.P., writing, review and editing, A.K. and D.P. All authors have read and agreed to the published version of the manuscript.

Funding: The present study was funded by RFBR according to Research Project No. 18-29-24186. Access to the electronic database of scientific publications was provided within Russian state assignment No. 075-00947-20-00.

Acknowledgments: The authors would like to appreciate The Center for Collective Use Testing Analytical Center of the JSC "Scientific-research institute of chemical technology" for chemical analysis.

Conflicts of Interest: The authors declare no conflict of interest.

\section{References}

1. Alumina Production. Available online: http://www.world-aluminium.org/statistics/alumina-production/ \#data (accessed on 16 March 2020).

2. Evans, K. The History, Challenges, and New Developments in the Management and Use of Bauxite Residue. J. Sustain. Metall. 2016, 2, 316-331. [CrossRef]

3. Xue, S.G.; Wu, Y.J.; Li, Y.W.; Kong, X.F.; Zhu, F.; William, H.; Li, X.F.; Ye, Y.Z. Industrial wastes applications for alkalinity regulation in bauxite residue: A comprehensive review. J. Cent. South Univ. 2019, 26, $268-288$. [CrossRef]

4. Sun, C.; Chen, J.; Tian, K.; Peng, D.; Liao, X.; Wu, X. Geochemical characteristics and toxic elements in alumina refining wastes and leachates from management facilities. Int. J. Environ. Res. Public Health 2019, 16, 1297. [CrossRef] [PubMed]

5. Pietrzyk-Sokulska, E.; Kulczycka, J. Impact of landfilling of red mud waste on local environment-The case of Górka. Gospod. Surowcami Min. Min. Resour. Manag. 2015, 31, 137-156. [CrossRef]

6. Cui, Y.; Chen, J.; Zhang, Y.; Peng, D.; Huang, T.; Sun, C. pH-Dependent Leaching Characteristics of Major and Toxic Elements from red mud. Int. J. Environ. Res. Public Health 2019, 16, 2046. [CrossRef] [PubMed]

7. Liu, Z.; Li, H. Metallurgical process for valuable elements recovery from red mud-A review. Hydrometallurgy 2015, 155, 29-43. [CrossRef]

8. Liu, Y.; Naidu, R. Hidden values in bauxite residue (red mud): Recovery of metals. Waste Manag. 2014, 34, 2662-2673. [CrossRef]

9. Zhang, T.; Wang, K.; Liu, Y.; Lyu, G.; Li, X.; Chen, X. A review of comprehensive utilization of high-iron red mud of China. In Light Metals 2020; The Minerals, Metals \& Materials Series; Tomsett, A., Ed.; Springer: Cham, Switzerland, 2020; pp. 65-71. [CrossRef]

10. Agrawal, S.; Rayapudi, V.; Dhawan, N. Extraction of Iron values from red mud. Mater. Today Proc. 2018, 5, 17064-17072. [CrossRef]

11. Kumar, R.; Srivastava, J.P. Utilization of iron values of red mud for metallurgical applications. In Environmental and Waste Management; Bandopadhyay, A., Goswami, N.G., Rao, P.R., Eds.; National Metallurgical Laboratory: Jamshedpur, India, 1998; pp. 108-119. [CrossRef]

12. Khairul, M.A.; Zanganeh, J.; Moghtaderi, B. The composition, recycling and utilisation of Bayer red mud. Resour. Conserv. Recycl. 2019, 141, 483-498. [CrossRef]

13. Borra, C.R.; Blanpain, B.; Pontikes, Y.; Binnemans, K.; Van Gerven, T. Recovery of rare earths and other valuable metals from bauxite residue (red mud): A review. J. Sustain. Met. 2016, 2, 365-386. [CrossRef] 
14. Deady, É.A.; Mouchos, E.; Goodenough, K.; Williamson, B.J.; Wall, F. A review of the potential for rare-earth element resources from European red muds: Examples from Seydişehir, Turkey and Parnassus-Giona, Greece. Miner. Mag. 2016, 80, 43-61. [CrossRef]

15. Zhang, N.; Li, H.X.; Liu, X.M. Recovery of scandium from bauxite residue-Red mud: A review. Rare Met. 2016, 35, 887-900. [CrossRef]

16. Akcil, A.; Akhmadiyeva, N.; Abdulvaliyev, R.; Meshram, A.; Meshram, P. Overview on extraction and separation of rare earth elements from red mud: Focus on scandium. Min. Process. Extr. Metall. Rev. 2018, 39, 145-151. [CrossRef]

17. Massari, S.; Ruberti, M. Rare earth elements as critical raw materials: Focus on international markets and future strategies. Resour. Policy 2013, 38, 36-43. [CrossRef]

18. Lima, M.S.S.; Thives, L.P.; Haritonovs, V.; Bajars, K. Red mud application in construction industry: Review of benefits and possibilities. Iop Conf. Ser. Mater. Sci. Eng. 2017, 251, 012033. [CrossRef]

19. Liu, X.; Zhang, N. Utilization of red mud in cement production: A review. Waste Manag. Res. 2011, 29, 1053-1063. [CrossRef]

20. Venkatesh, C.; Chand, M.S.R.; Nerella, R. A state of the art on red mud as a substitutional cementitious material. Ann. Chim. Sci. Des Mater. 2019, 43, 99-106. [CrossRef]

21. Kumar, M.; Senapati, B.; Kumar, C.S. Management of industrial waste: The case of effective utilization of red mud and fly ash at Vedanta Aluminium Limited—Lanjigarh. In Light Metals 2013; The Minerals, Metals \& Materials Series; Sadler, B., Ed.; Springer: Cham, Switzerland, 2016; pp. 119-123. [CrossRef]

22. Sglavo, V.M.; Maurina, S.; Conci, A.; Salviati, A.; Carturan, G.; Cocco, G. Bauxite "red mud" in the ceramic industry. Part 2: Production of clay-based ceramics. J. Eur. Ceram. Soc. 2000, 20, 245-252. [CrossRef]

23. Hertel, T.; Pontikes, Y. Geopolymers, inorganic polymers, alkali-activated materials and hybrid binders from bauxite residue (red mud)—Putting things in perspective. J. Clean. Prod. 2020, 258, 120610. [CrossRef]

24. Bhatnagar, A.; Vilar, V.J.P.; Botelho, C.M.S.; Boaventura, R.A.R. A review of the use of red mud as adsorbent for the removal of toxic pollutants from water and wastewater. Environ. Technol. 2011, 32, 231-249. [CrossRef]

25. Sushil, S.; Batra, V.S. Catalytic applications of red mud, an aluminium industry waste: A review. Appl. Catal. B Environ. 2008, 81, 64-77. [CrossRef]

26. Wang, S.; Ang, H.M.; Tadé, M.O. Novel applications of red mud as coagulant, adsorbent and catalyst for environmentally benign processes. Chemosphere 2008, 72, 1621-1635. [CrossRef] [PubMed]

27. Itskov, Y. Red Mud: Problem and Solutions. Available online: https://www.metalbulletin.com/events/ download.ashx/document/speaker/7453/a0ID000000X0k8RMAR/Presentation (accessed on 19 March 2020).

28. Keskinkilic, E.; Pournaderi, S.; Geveci, A.; Topkaya, Y.A. Solid-state reduction studies for recovery of iron from red mud. In 11th International Symposium on High-Temperature Metallurgical Processing; The Minerals, Metals \& Materials Series; Peng, Z., Ed.; Springer: Cham, Switzerland, 2020; pp. 511-519. [CrossRef]

29. Keskinkilic, E.; Pournaderi, S.; Geveci, A.; Topkaya, Y.A. Smelting studies for recovery of iron from red mud. In 10th International Symposium on High-Temperature Metallurgical Processing; The Minerals, Metals \& Materials Series; Jiang, T., Hwang, J.-Y., Gregurek, D., Peng, Z.W., Downey, J.P., Zhao, B.J., Eds.; Springer: Cham, Switzerland, 2019; pp. 489-499. [CrossRef]

30. Long, H.; Meng, Q.; Chun, T.; Wang, P.; Li, J. Preparation of metallic iron powder from copper slag by carbothermic reduction and magnetic separation. Can. Metall. Q. 2016, 55, 338-344. [CrossRef]

31. Zhang, Y.; Li, H.; Yu, X. Recovery of iron from cyanide tailings with reduction roasting-water leaching followed by magnetic separation. J. Hazard. Mater. 2012, 213-214, 167-174. [CrossRef]

32. Park, J.W.; Ahn, J.C.; Song, H.; Park, K.; Shin, H.; Ahn, J.S. Reduction characteristics of oily hot rolling mill sludge by direct reduced iron method. Resour. Conserv. Recycl. 2002, 34, 129-140. [CrossRef]

33. Khaki, J.V.; Shalchian, H.; Rafsanjani-Abbasi, A.; Alavifard, N. Recovery of iron from a high-sulfur and low-grade iron ore. Thermochim. Acta 2018, 662, 47-54. [CrossRef]

34. Yu, W.; Sun, T.; Kou, J.; Wei, Y.; Xu, C.; Liu, Z. The function of $\mathrm{Ca}(\mathrm{OH})_{2}$ and $\mathrm{Na}_{2} \mathrm{CO}_{3}$ as additive on the reduction of high-phosphorus oolitic hematite-coal mixed pellets. ISIJ Int. 2013, 53, 427-433. [CrossRef]

35. Zhu, D.Q.; Chun, T.J.; Pan, J.; Lu, L.M.; He, Z. Upgrading and dephosphorization of Western Australian iron ore using reduction roasting by adding sodium carbonate. Int. J. Min. Met. Mater. 2013, 20, 505-513. [CrossRef]

36. Qu, G.; Zhou, S.; Wang, H.; Li, B.; Wei, Y. Production of ferronickel concentrate from low-grade nickel laterite ore by non-melting reduction magnetic separation process. Metals 2019, 9, 1340. [CrossRef] 
37. Ma, B.; Xing, P.; Yang, W.; Wang, C.; Chen, Y.; Wang, H. Solid-state metalized reduction of magnesium-rich low-nickel oxide ores using coal as the reductant based on thermodynamic analysis. Met. Mater. Trans. $B$ Process Met. Mater. Process. Sci. 2017, 48, 2037-2046. [CrossRef]

38. Zhu, D.; Pan, L.; Guo, Z.; Pan, J.; Zhang, F. Utilization of limonitic nickel laterite to produce ferronickel concentrate by the selective reduction-magnetic separation process. Adv. Powder Technol. 2019, 30, 451-460. [CrossRef]

39. Chun, T.J.; Zhu, D.Q.; Pan, J.; He, Z. Preparation of metallic iron powder from red mud by sodium salt roasting and magnetic separation. Can. Metall. Q. 2014, 53, 183-189. [CrossRef]

40. Cardenia, C.; Balomenos, E.; Panias, D. Iron recovery from bauxite residue through reductive roasting and wet magnetic separation. J. Sustain. Metall. 2019, 5, 9-19. [CrossRef]

41. Zhu, D.; Chun, T.; Pan, J.; He, Z. Recovery of iron from high-iron red mud by reduction roasting with adding sodium salt. J. Iron Steel Res. Int. 2012, 19, 1-5. [CrossRef]

42. Li, G.; Liu, M.; Rao, M.; Jiang, T.; Zhuang, J.; Zhang, Y. Stepwise extraction of valuable components from red mud based on reductive roasting with sodium salts. J. Hazard. Mater. 2014, 280, 774-780. [CrossRef]

43. Suprapto, S.; Istiqomah, Z.; Santoso, E.; Dawam, A.A.; Prasetyoko, D. Alumina extraction from red mud by magnetic separation. Indones. J. Chem. 2018, 18, 331-336. [CrossRef]

44. Rao, M.; Zhuang, J.; Li, G.; Zeng, J.; Jiang, T. Iron recovery from red mud by reduction roasting-magnetic separation. In Light Metals 2013; The Minerals, Metals \& Materials Series; Sadler, B.A., Ed.; Springer: Cham, Switzerland, 2016; pp. 125-130. [CrossRef]

45. Grudinskii, P.I.; Zinoveev, D.V.; Semenov, A.F.; Zakunov, A.S.; Dyubanov, V.G.; Petelin, A.L. Advanced method for recycling red mud by carbothermal solid-phase reduction using sodium sulfate. Metallurgist 2020, 63, 15-21. [CrossRef]

46. Ding, W.; Xiao, J.-H.; Peng, Y.; Shen, S.-Y.; Chen, T. Iron extraction from red mud using roasting with sodium salt. Min. Process. Extr. Met. Rev. 2019. [CrossRef]

47. Chun, T.; Li, D.; Di, Z.; Long, H.; Tang, L.; Li, F.; Li, Y. Recovery of iron from red mud by hightemperature reduction of carbonbearing briquettes. J. S. Afr. Inst. Min. Metall. 2017, 117, 361-364. [CrossRef]

48. Zinoveev, D.; Grudinsky, P.; Zakunov, A.; Semenov, A.; Panova, M.; Valeev, D.; Kondratiev, A.; Dyubanov, V.; Petelin, A. Influence of $\mathrm{Na}_{2} \mathrm{CO}_{3}$ and $\mathrm{K}_{2} \mathrm{CO}_{3}$ addition on iron grain growth during carbothermic reduction of red mud. Metals 2019, 9, 1313. [CrossRef]

49. Ding, W.; Peng, Y.; Wu, Q.; Shen, S.; Xiao, J.; Liang, G.; Huang, W. Increase of iron concentration and reduction of impurities in red mud from the Wenshan area of Yunnan Province by segregation roasting-low intensity magnetic separation. J. Mines Met. Fuels 2019, 67, 377-384.

50. Huang, Z.-C.; Cai, L.-B.; Zhang, Y.; Yang, Y.-B.; Jiang, T. Reduction of iron oxides of red mud reinforced by $\mathrm{Na}_{2} \mathrm{CO}_{3}$ and $\mathrm{CaF}_{2}$. Zhongnan Daxue Xuebao Ziran Kexue Ban J. Cent. South Univ. Sci. Technol. 2010, 41, 838-844.

51. Lv, W.; Bai, C.; Lv, X.; Hu, K.; Lv, X.; Xiang, J.; Song, B. Carbothermic reduction of ilmenite concentrate in semi-molten state by adding sodium sulfate. Powder Technol. 2018, 340, 354-361. [CrossRef]

52. Gao, E.X.; Sun, T.C.; Liu, Z.G.; Geng, C.; Xu, C.Y. Effect of sodium sulfate on direct reduction of beach titanomagnetite for separation of iron and titanium. J. Iron Steel Res. Int. 2016, 23, 428-433. [CrossRef]

53. Zhu, D.; Guo, Z.; Pan, J.; Zhang, F. Synchronous upgrading iron and phosphorus removal from high phosphorus Oolitic hematite ore by high temperature flash reduction. Metals 2016, 6, 123. [CrossRef]

54. Liu, Y.; Lv, X.; You, Z.; Lv, X. Kinetics study on non-isothermal carbothermic reduction of nickel laterite ore in presence of $\mathrm{Na}_{2} \mathrm{SO}_{4}$. Powder Technol. 2020, 362, 486-492. [CrossRef]

55. Rao, M.; Li, G.; Zhang, X.; Luo, J.; Peng, Z.; Jiang, T. Reductive roasting of nickel laterite ore with sodium sulphate for Fe-Ni production. Part II: Phase transformation and grain growth. Sep. Sci. Technol. 2016, 51, 1727-1735. [CrossRef]

56. Wang, X.P.; Sun, T.C.; Chen, C.; Kou, J. Effects of $\mathrm{Na}_{2} \mathrm{SO}_{4}$ on iron and nickel reduction in a high-iron and low-nickel laterite ore. Int. J. Min. Metall. Mater. 2018, 25, 383-390. [CrossRef]

57. Grudinskii, P.I.; Dyubanov, V.G.; Zinoveev, D.V.; Zheleznyi, M.V. Solid-phase reduction and iron grain growth in red mud in the presence of alkali metal salts. Russ. Met. 2018, 2018, 1020. [CrossRef]

58. Meher, S.N.; Rout, A.; Padhi, B.K. Extraction of alumina from red mud by divalent alkaline earth metal soda ash sinter process. In Light Metals 2011; Lindsay, S.J., Ed.; Springer: Cham, Switzerland, 2011; pp. 231-236. 
59. Anisonyan, K.G.; Kopyev, D.Y.; Olyunina, T.V.; Sadykhov, G.B. Influence of $\mathrm{Na}_{2} \mathrm{CO}_{3}$ and $\mathrm{CaCO}_{3}$ additions on the aluminate slag formation during a single-stage reducing roasting of red mud. Non-Ferr. Met. 2019, 17-21. [CrossRef]

60. Tam, P.W.Y.; Panias, D.; Vassiliadou, V. Sintering optimisation and recovery of aluminum and sodium from greek bauxite residue. Minerals 2019, 9, 571. [CrossRef]

61. Fan, D.C.; Ni, W.; Yan, A.Y.; Wang, J.Y.; Cui, W.H. Orthogonal experiments on direct reduction of carbon-bearing pellets of bayer red mud. J. Iron Steel Res. Int. 2015, 22, 686-693. [CrossRef]

62. Gao, F.; Zhang, J.; Deng, X.; Wang, K.; He, C.; Li, X.; Wei, Y. Comprehensive recovery of iron and aluminum from ordinary bayer red mud by reductive sintering-magnetic separation-digesting process. JOM 2019, 71 , 2936-2943. [CrossRef]

63. Shiryaeva, E.V.; Podgorodetskiy, G.S.; Malyscheva, T.Y.; Gorbunov, V.B.; Zavodyaniy, A.V.; Schapovalov, A.N. Influence of low alkaline red mud on the properties and microstructure of the agglomerates from the charge materials JSC “Ural steel”. Izv. Ferr. Met. 2014, 57, 14-19. [CrossRef]

64. HSC Chemistry, version 9.9; software for chemical reaction and equilibrium calculation; Outotec: Pori, Finland, 2019.

65. Match!; Version 3.10; Software for Phase Analysis Using Powder Diffraction; Crystal Impact: Bonn, Germany, 2019.

66. Pankratov, D.A.; Anuchina, M.M.; Spiridonov, F.M.; Krivtsov, G.G. $\mathrm{Fe}_{3-\delta} \mathrm{O}_{4}$ nanoparticles synthesized in the presence of natural polyelectrolytes. Crystallogr. Rep. 2020, 65, 393-397. [CrossRef]

67. Valeev, D.; Zinoveev, D.; Kondratiev, A.; Lubyanoi, D.; Pankratov, D. Reductive smelting of neutralized red mud for iron recovery and produced pig iron for heat-resistant castings. Metals 2020, 10, 32. [CrossRef]

68. Oh, S.J.; Cook, D.C.; Townsend, H.E. Characterization of iron oxides commonly formed as corrosion products on steel. Hyperfine Interact. 1998, 112, 59-66. [CrossRef]

69. Vodyanitskii, Y.N.; Minkina, T.M.; Kubrin, S.P.; Pankratov, D.A.; Fedorenko, A.G. Common and rare iron, sulfur, and zinc minerals in technogenically contaminated hydromorphic soil from Southern Russia. Environ. Geochem. Health 2020, 42, 95-108. [CrossRef]

70. Hairi, S.N.M.; Jameson, G.N.L.; Rogers, J.J.; MacKenzie, K.J.D. Synthesis and properties of inorganic polymers (geopolymers) derived from Bayer process residue (red mud) and bauxite. J. Mater. Sci. 2015, 50, 7713-7724. [CrossRef]

71. Vandenberghe, R.E.; Barrero, C.A.; Da Costa, G.M.; Van San, E.; De Grave, E. Mössbauer characterization of iron oxides and (oxy)hydroxides: The present state of the art. Hyperfine Interact. 2000, 126, 247-259. [CrossRef]

72. Rostovshchikova, T.N.; Korobov, M.S.; Pankratov, D.A.; Yurkov, G.Y.; Gubin, S.P. Catalytic conversions of chloroolefins over iron oxide nanoparticles 2. Isomerization of dichlorobutenes over iron oxide nanoparticles stabilized on the surface of ultradispersed poly(tetrafluoroethylene). Russ. Chem. Bull. 2005, 54, 1425-1432. [CrossRef]

73. Jónás, K.; Solymár, K.; Zöldi, J. Some applications of mössbauer spectroscopy for the quantitative analysis of minerals and mineral mixtures. J. Mol. Struct. 1980, 60, 449-452. [CrossRef]

74. Morin, F.J. Magnetic susceptibility of $\alpha \mathrm{Fe}_{2} \mathrm{O}_{3}$ and $\alpha \mathrm{Fe}_{2} \mathrm{O}_{3}$ with added titanium. Phys. Rev. 1950, 78, 819-820. [CrossRef]

75. Van San, E.; De Grave, E.; Vandenberghe, R.E.; Desseyn, H.O.; Datas, L.; Barrón, V.; Rousset, A. Study of Al-substituted hematites, prepared from thermal treatment of lepidocrocite. Phys. Chem. Min. 2001, 28, 488-497. [CrossRef]

76. Pankratov, D.A. Mössbauer study of oxo derivatives of iron in the $\mathrm{Fe}_{2} \mathrm{O}_{3}-\mathrm{Na}_{2} \mathrm{O}_{2}$ system. Inorg. Mater. 2014, 50, 82-89. [CrossRef]

77. Khalil, M.I. Crystal chemistry and Mössbauer spectroscopic analysis of clays around Riyadh for brick industry. Hyperfine Interact. 2013, 218, 113-121. [CrossRef]

78. Karimi, E.; Teixeira, I.F.; Ribeiro, L.P.; Gomez, A.; Lago, R.M.; Penner, G.; Kycia, S.W.; Schlaf, M. Ketonization and deoxygenation of alkanoic acids and conversion of levulinic acid to hydrocarbons using a red mud bauxite mining waste as the catalyst. Catal. Today 2012, 190, 73-88. [CrossRef]

79. Ammasi, A. Effect of heating rate on decomposition temperature of goethite ore. Trans. Indian Inst. Met. 2020, 73, 93-98. [CrossRef] 
80. Yang, J.; Mori, T.; Kuwabara, M. Mechanism of carbothermic reduction of hematite in hematite-carbon composite pellets. ISIJ Int. 2007, 47, 1394-1400. [CrossRef]

81. Jiang, M.; Sun, T.; Liu, Z.; Kou, J.; Liu, N.; Zhang, S. Mechanism of sodium sulfate in promoting selective reduction of nickel laterite ore during reduction roasting process. Int. J. Min. Process. 2013, 123, 32-38. [CrossRef]

82. Rayzman, V.; Filipovich, I.; Nisse, L.; Vlasenko, Y. Sodium aluminate from alumina-bearing intermediates and wastes. JOM 1998, 50, 32-37. [CrossRef]

83. Pankratov, D.A.; Anuchina, M.M. Nature-inspired synthesis of magnetic non-stoichiometric $\mathrm{Fe}_{3} \mathrm{O}_{4}$ nanoparticles by oxidative in situ method in a humic medium. Mater. Chem. Phys. 2019, 231, 216-224. [CrossRef]

84. Sauer, W.E.; Reynik, R.J. Electronic and magnetic structure of dilute iron-base alloys. J. Appl. Phys. 1971, 42, 1604-1605. [CrossRef]

85. Vincze, I.; Campbell, I.A. Mossbauer measurements in iron based alloys with transition metals. J. Phys. F Met. Phys. 1973, 3, 647-663. [CrossRef]

86. Dubiel, S.M.; Cieslak, J. Short-range order in iron-rich Fe-Cr alloys as revealed by Mössbauer spectroscopy. Phys. Rev. B Condens. Matter Mater. Phys. 2011, 83, 10-13. [CrossRef]

87. Haneda, K.; Zhou, Z.X.; Morrish, A.H.; Majima, T.; Miyahara, T. Low-temperature stable nanometer-size fcc-Fe particles with no magnetic ordering. Phys. Rev. B 1992, 46, 13832-13837. [CrossRef]

88. Ding, J.; Huang, H.; Mccormick, P.G.; Street, R. Magnetic properties of martensite-austenite mixtures in mechanically milled 304 stainless steel. J. Magn. Magn. Mater. 1995, 139, 109-114. [CrossRef]

89. Le Caer, G.; Dubois, J.M.; Senateur, J.P. Etude par spectrométrie Mössbauer des carbures de Fer $\mathrm{Fe}_{3} \mathrm{C}$ et $\mathrm{Fe}_{5} \mathrm{C}_{2}$. J. Solid State Chem. 1976, 19, 19-28. [CrossRef]

90. Baskakov, A.O.; Starchikov, S.S.; Lyubutin, I.S.; Ogarkova, Y.L.; Davydov, V.A.; Kulikova, L.F.; Egorova, T.B.; Agafonov, V.N.; Starchikova, I.Y. Distribution of iron atoms in nonequivalent crystallographic Sites of $\mathrm{Fe}_{7} \mathrm{C}_{3}$ carbide in core-shell nanostructures. Crystallogr. Rep. 2019, 64, 331-336. [CrossRef]

91. Jiraskova, Y.; Pizurova, N.; Titov, A.; Janickovic, D.; Friak, M. Phase separation in Fe-Ti-Al alloy-Structural, magnetic, and Mössbauer study. J. Magn. Magn. Mater. 2018, 468, 91-99. [CrossRef]

92. Bai, S.; Wen, S.; Liu, S.; Zhang, W.; Xian, Y. Catalyzing carbothermic reduction of siderite ore with high content of phosphorus by adding sodium carbonate. ISIJ Int. 2011, 51, 1601-1607. [CrossRef]

93. Sadangi, J.K.; Das, S.P.; Tripathy, A.; Biswal, S.K. Investigation into recovery of iron values from red mud dumps. Sep. Sci. Technol. 2018, 53, 2186-2191. [CrossRef]

94. Liu, W.; Yang, J.; Xiao, B. Application of Bayer red mud for iron recovery and building material production from alumosilicate residues. J. Hazard. Mater. 2009, 161, 474-478. [CrossRef] [PubMed]

95. Iron Carbide for Electric Arc Furnaces. Available online: http://iicarbide.com/archives/IIC_iron_carbide_for_ EAFs_rev_02.pdf (accessed on 20 August 2020).

96. Svoboda, J. Practical aspects of magnetic methods for materials treatment. In Magnetic Techniques for the Treatment of Materials; Springer: Dordrecht, The Netherlands, 2006; pp. 319-467.

97. Li, G.; Shi, T.; Rao, M.; Jiang, T.; Zhang, Y. Beneficiation of nickeliferous laterite by reduction roasting in the presence of sodium sulfate. Min. Eng. 2012, 32, 19-26. [CrossRef]

98. Li, F.; Franzen, H.F. Phase transitions in near stoichiometric iron sulfide. J. Alloys Compd. 1996, 238 , 73-80. [CrossRef]

99. Yu, W.; Sun, T.; Cui, Q. Can sodium sulfate be used as an additive for the reduction roasting of high-phosphorus oolitic hematite ore? Int. J. Min. Process. 2014, 133, 119-122. [CrossRef]

100. Onghena, B.; Binnemans, K. Recovery of Scandium(III) from aqueous solutions by solvent extraction with the functionalized ionic liquid betainium bis(trifluoromethylsulfonyl)imide. Ind. Eng. Chem. Res. 2015, 54, 1887-1898. [CrossRef]

Publisher's Note: MDPI stays neutral with regard to jurisdictional claims in published maps and institutional affiliations. 